\title{
Mortality of employees of the Atomic Weapons Establishment, 1951-82
}

\author{
Valerie Beral, Patricia Fraser, Lucy Carpenter, Margaret Booth, Ann Brown, Geoffrey Rose
}

\begin{abstract}
A total of 22552 workers employed by the Atomic Weapons Establishment between 1951 and 1982 were followed up for an average of 18.6 years. Of the 3115 who died, $865(28 \%)$ died of cancer. Mortality was $23 \%$ lower than the national average for all causes of death and $18 \%$ lower for cancer. These low rates were consistent with the findings in other workforces in the nuclear industry and reflect, at least in part, the selection of healthy people to work in the industry and the disproportionate recruitment of people from the higher social classes.

At some time during their employment 9389 (42\%) of the workers were monitored for exposure to radiation, the average cumulative whole body exposure to external radiation being $7.8 \mathrm{mSv}$. Their mortality was generally similar to that of other employees, even when exposures were lagged by 10 years. The rate ratio after a 10 year lag in workers with a radiation record compared with other workers was 1.01 (95\% confidence interval 0.92 to 1.10$)$ for all causes of death and $1.06(0.89$ to 1.27$)$ for all malignant neoplasms. The only significant differences were for prostatic cancer (rate ratio 2.23; $95 \%$ confidence interval 1.13 to 4.40 ) and for cancers of ill defined and secondary sites (rate ratio $2.37 ; 1.23$ to 4.56 ). Cancers of lymphatic and haemopoietic tissues were notable for their low occurrence in the study population, with only four deaths from leukaemia and two from multiple myeloma in workers with a radiation record, 9.16 and 3.55 deaths respectively being expected on the basis of national rates.
\end{abstract}

Among workers who had a radiation record 3742 $(40 \%)$ were also monitored for possible internal exposure to plutonium, $3044(32 \%)$ to uranium, $1562(17 \%)$ to tritium, $638(7 \%)$ to polonium, and $281(3 \%)$ to actinium. In these workers mortality from malignant neoplasms as a whole was not increased, but after a $\mathbf{1 0}$ year lag death rates from prostatic and renal cancers were generally more than twice the national average, these excesses arising in a small group of workers monitored for exposure to multiple radionuclides. Though mortality from lung cancer in workers monitored for exposure to plutonium was below the national average, it was some two thirds higher than in other radiation workers, the excess being of borderline statistical significance.

Mortality from malignant neoplasms as a whole showed a weak and non-significant increasing trend with increasing level of cumulative whole body exposure to external radiation. When the exposures were lagged by 10 years the trend became stronger and significant, the estimated increase in relative risk per $10 \mathrm{mSv}$ being $7.6 \%$ (95\% confidence interval $0.4 \%$ to $15.3 \%$ ). This trend was confined almost entirely to workers who were also monitored for exposure to radionuclides $(\mathbf{p}<0.001)$, the main contributions coming from lung cancer and prostatic cancer. Exposures of the lung and prostate from internal sources of radiation were not quantified, except for the contribution from tritium. It was therefore not possible to assess the extent to which the associations were due to internally deposited radionuclides rather than external exposure.

The findings for prostatic cancer taken in conjunction with the results of other studies suggest a specific occupational hazard in a small group of workers in the nuclear industry who had comparatively high exposures to external radiation and who were also monitored for internal exposure to multiple radionuclides. Research is needed to discover whether any of the radionuclides and other substances concerned are concentrated in the prostate. The occurrence of lung cancer in this workforce requires further investigation taking into account smoking habits and tissue doses from inhaled radionuclides.

\section{Introduction}

The continuing debate on the magnitude of the risk of cancer associated with repeated exposures to low doses of ionising radiation has prompted studies of the incidence of cancer and mortality in workers in the nuclear industry. ${ }^{1-14}$ In 1981 the Ministry of Defence approached the Medical Research Council requesting the appointment of an independent research group to study the mortality of workers engaged in atomic weapons research. Members of the Epidemiological Monitoring Unit who were already studying mortality in employees of the United Kingdom Atomic Energy Authority ${ }^{6711}$ undertook the task. Progress of the study was reviewed regularly by a subcommittee of the Medical Research Council Committee on the Effects of Ionising Radiation.

The mortality of two nuclear industrial workforces in the United Kingdom has been described. In both the death rates from cancer and other causes were below national and local rates and were generally similar in workers who were monitored for exposure to radiation and the remaining workforce. ${ }^{710}$ Among 40000 employees of the United Kingdom Atomic Energy Authority the mortality from prostatic cancer was significantly increased in workers who had been monitored for internal exposure to radionuclides and who also had comparatively high exposures to external radiation. ${ }^{711}$ In 14000 employees at the Sellafield plant of British Nuclear Fuels mortality from multiple myeloma, all lymphatic and haemopoietic neoplasms, and bladder cancer was related to dose of external radiation, but only after allowing for a latency of 15 years. ${ }^{10}$

Nuclear workers in the United States are also reported to have lower mortality than the national 
average..$^{1.58912-14}$ In the 21000 workers at Hanford in Washington State the only cause of death consistently shown to be related to exposure to external radiation was multiple myeloma. ${ }^{1+}$ Mortality from tumours of brain and nervous system was above the national average in a nuclear fuels plant in Connecticut ${ }^{3}$ and at the Rocky Flats nuclear weapons plant in Colorado, but the occurrence of these tumours could not be related to exposure to plutonium, external radiation, or any other occupational factor. ${ }^{5}$ Within the Rocky Flats workforce a non-significant excess mortality from oesophageal, gastric, intestinal, prostatic, and lymphatic cancers was observed in workers with body burdens of $74 \mathrm{~Bq}(2 \mathrm{nCi})$ or more of plutonium compared with workers with lower body burdens. ${ }^{12}$ In the 8000 employees of the Oak Ridge National Laboratory in Tennessee mortality from leukaemia and prostatic cancer was above the national average, though not significantly so. ${ }^{8}$ At the Y-12 nuclear weapons materials fabrication plant in Oak Ridge a significantly increased mortality from lung cancer was found among the 7000 employees studied, the excess being most pronounced in workers with comparatively high exposures to both internal and external radiation. ${ }^{13}$ Mortality from leukaemia and all malignant neoplasms was not above the national average in the 25000 employees of the Portsmouth Naval Shipyard in New England, ${ }^{2}$ but after allowing for a latency of 15 years there was a significant excess mortality from lung cancer in the more heavily exposed workers. ${ }^{14}$

Atomic weapons research began in Britain in 1947 under the auspices of the Ministry of Supply, the forerunner of the United Kingdom Atomic Energy Authority. The movement to Aldermaston of atomic weapons research activities began in April 1950, to the site which later became known as the Atomic Weapons Research Establishment; this was to become the main part of the weapons group of the United Kingdom Atomic Energy Authority when the authority was set up in 1954. In April 1973 control passed to the Ministry of Defence and in September 1987 the site was renamed the Atomic Weapons Establishment. The mortality of 22552 employees of the Atomic Weapons Establishment at Aldermaston and associated estabushments is described here.

\section{Methods}

The design of the Atomic Weapons Establishment mortality study and methods of data collection and validation were similar to those adopted in the United Kingdom Atomic Energy Authority mortality study. ${ }^{6}$ Much of the day to day clerical work, processing of personnel and radiation data, and merging of computerised records was contracted out to the United Kingdom Atomic Energy Authority by the Atomic Weapons Establishment and performed by the same experienced staff concerned in the United Kingdom Atomic Energy Authority study, using a similar detailed protocol. All work was scrutinised by staff of the Epidemiological Monitoring Unit, who checked a $1 \%$ random sample of abstracted records for transcription errors, organised the follow up of exemployees, and assembled the mortality data.

\section{STUDY POPULATION AND PERSONNEL DATA}

The study population included all employees of the atomic weapons research establishments at Aldermaston, Fort Halstead, Orfordness, Foulness, and Woolwich Common who were employed at any time from 1 January 1951 to 31 December 1982. All employees were included irrespective of their duration of employment. Attached workers, contractors' staff, and students with vacation jobs were excluded because of uncertainties about the completeness of their records.
Personnel records, which were held at Aldermaston for all the above establishments, were used to define the Atomic Weapons Establishment study population. Statistics for the manpower strength of the United Kingdom Atomic Energy Authority's weapons group during 1949 to 1973 (United Kingdom Atomic Energy Authority, personal communication) suggested that personnel records were complete for 1951 to 1973 but that the archives were incomplete before 1951, a period when the size of the workforce was very small compared with later years. For each year from 1951 the numbers of employees in the study population agreed closely with the authority's figures. No independently collected statistics existed against which the completeness of the study population after 1973 could be assessed.

Personnel record cards and, since about 1970, computerised records were the primary sources of personal details required in the study - that is, name, address, sex, date of birth, establishment, works number, dates of entering and terminating employment, and employment grade on leaving. Employment grade was coded as in the United Kingdom Atomic Energy Authority study to enable workers to be assigned a social class based on the Registrar General's classification of occupations, $1970 .{ }^{6}{ }^{15}$ Personnel data were checked by computer for errors, omissions, and inconsistencies and amended where necessary.

\section{MORTALITY DATA}

Details of employees leaving the Atomic Weapons Establishment on or before 31 December 1982 were submitted for tracing to the NHS Central Register. For subjects recorded as having died both the underlying and associated causes of death as stated on the death certificate were coded to the eighth and ninth revisions of the International Classification of Diseases (ICD) $)^{16}$ by the Office of Population Censuses and Surveys. Coded death certificates and notifications of emigrations were sent direct to the Epidemiological Monitoring Unit. With the permission of the central ethical committee of the BMA the NHS Central Register also provided information on cancer registrations in a depersonalised form. When a person could not be traced at the central register or was aged 80 or more at the end of the study period identifying particulars were sent to the Department of Health and Social Security's records branch. When the DHSS could provide additional information the details were resubmitted to the NHS Central Register.

Though ascertaining death from external sources was an important principle of the study, the Atomic Weapons Establishment's records provided a cross check on the completeness of notification of death. All but 29 of the 779 deaths recorded in the Atomic Weapons Establishment's medical records and the 1293 deaths recorded in its pensions records had been notified to the Epidemiological Monitoring Unit by the NHS Central Register. These 29 deaths were included in the analyses, death certificates subsequently being obtained for 20 of them. Data held at the Oxford Cancer Registry and the department of haematology of the Royal Berkshire Hospital (C Barton, personal communication) were used to provide an independent check that deaths from cancer had not been missed. These sources identified 50 deaths from cancer, including five from leukaemia, in people for whom the Atomic Weapons Establishment was mentioned as their employer and all subjects and deaths were found to have already been included in the study.

\section{RADIATION DATA}

Since 1964 personal records of exposure to radiation at the Atomic Weapons Establishment have been 
stored on computer. Records for earlier years have been incorporated into the system by clerks using a standard protocol. These computerised files were used to identify each employee for whom a record of monitoring for radiation exposure existed in the Atomic Weapons Establishment's health physics department or its archives. Data abstracted for each employee included a yearly summary of exposure to $x$ and $\gamma$ rays, to neutrons, and to "surface dose" ( $x$ rays $+\gamma$ rays + neutrons $+\beta$ particles). Information on exposure from internal sources of irradiation, such as plutonium, uranium, polonium, or actinium, was limited to noting the years in which subjects were monitored for possible internal contamination by each radionuclide and the number of times they were monitored. For tritium yearly assessed doses were also included. Other relevant details abstracted were yearly summaries of the numbers of dosimeter readings which were below the threshold of the measuring devices in use at the time, and the proportion of the year for which dosimeter readings were missing because the films had been lost or damaged. Exposure accumulated in previous employments was included when recorded in Atomic Weapons Establishment records. For workers who had also been employed by the United Kingdom Atomic Energy Authority previous or subsequent exposures, or both, were included.

Computer checks were carried out on all radiation data before they were computer matched to the personnel data. When possible, works number and establishment, name, age, and a check on the consistency between dates of employment and radiation monitoring were used to establish a unique match. Recourse to personnel records was necessary when a unique match could not be achieved. Health physics records for 85 people with inadequate identifying particulars could not be matched to any personnel record. Their collective exposure was $191 \mathrm{mSv} ; 45 \mathrm{had}$ no recorded exposure and only five had a cumulative exposure exceeding $10 \mathrm{mSv}$. The linked file of personnel and radiation data was depersonalised before being sent to the Epidemiological Monitoring Unit for merging with the follow up data before analysis. No information on mortality was passed to the Atomic Weapons Establishment until all the radiation data had been received.

\section{DEFINITIONS IN ASSESSING RADIATION EXPOSURE}

Radiation exposure from external sources consists of several components measured on dosimeters. $x$ Rays, $\gamma$ rays, and neutrons each contribute to penetrating (or whole body) radiation, and, in addition, $\beta$ radiation and low energy photons contribute to non-penetrating (or surface) radiation. The doses recorded on dosimeters worn externally are not direct measurements of the doses absorbed by specific tissues, so the term "exposure" rather than "dose" is used to describe the measurements, though millisieverts $(\mathrm{mSv})$ are retained as the unit of measurement. "Whole body exposure" is defined as the sum of external dosimeter readings for $x$ rays, $\gamma$ rays, and neutrons with the appropriate corrections for quality factor. "Surface exposure" is defined as the sum of the dosimeter readings for $x$ rays, $\gamma$ rays, neutrons, and $\beta$ irradiation. No specific account was taken of medical exposure to $x$ rays or background radiation, except that they were assumed to be similar on average in the groups of workers whose mortality was compared.

Absorbed doses from plutonium, uranium, polonium, or actinium, exposure to which was mostly in the form of insoluble compounds, were not estimated because the dose may vary considerably from one organ to another depending on the specific radionuclide, its route of entry into the body, its chemical form, and its time course of retention. Furthermore, the intake and deposition of these radionuclides are often difficult to assess from external measurements. In contrast, tritium is evenly distributed in the body; whole body exposures can readily be assessed and so were included.

For employees with a radiation record the yearly dosimeter readings for external whole body exposure were cumulated, assigning zero to below threshold measurements and estimating exposures for lost or damaged films. The conventions for threshold and missing values adopted took account of the detailed analysis of similar data in the United Kingdom Atomic Energy Authority study. ${ }^{11} 18$ The exposure assigned in any year for missing values was the appropriate fraction of the worker's recorded dose in that year. If dosimeter readings were missing for more than nine months in any one year (which occurred in $0.01 \%$ of records) the recorded dose was taken to represent that accumulated over three months. A threshold reading was the lowest value attributed in the record to any single measurement when the actual measurement was lower. At the Atomic Weapons Establishment the threshold was $0.1 \mathrm{mSv}$ in $1950-6$ and $0.2 \mathrm{mSv}$ in 1957-61, whereas at the United Kingdom Atomic Energy Authority (Harwell) it was $0.5 \mathrm{mSv}$ until 1961 . Dosimeters were issued fortnightly by the Atomic Weapons Establishment up to 1956 and monthly thereafter, whereas they were issued weekly at Harwell. Before 1961 the maximum yearly exposure which could be recorded as threshold was therefore $2.6 \mathrm{mSv}$ at the Atomic Weapons Establishment, but $26.0 \mathrm{mSv}$ at Harwell, the scope for error thus being an order of magnitude greater at the United Kingdom Atomic Energy Authority than the Atomic Weapons Establishment. After 1961 both organisations adopted thresholds of around $0.05 \mathrm{mSv}$ and issued dosimeters every four weeks, later every calendar month, so the maximum dose included in threshold values could be no more than $0.65 \mathrm{mSv}$ a year.

Workers were grouped in several ways for statistical analysis. In keeping with other studies in the United Kingdom, workers who had a radiation record were separated from workers who had no such record..$^{7111}$ Exposure to radionuclides was considered in a similar way, workers with a radiation record being further separated into those who had and had not been monitored for internal exposure to specific radionuclides. Workers with a radiation record were further divided into five groups according to recorded cumulative exposure to external radiation, the categories being $<10,10-, 20-, 50-$, and $\geqslant 100 \mathrm{mSv}$, as in the United Kingdom Atomic Energy Authority study. As most workers with a radiation record accumulated low or even no measured external exposure, a further classification was made according to whether the worker had accumulated at least $10 \mathrm{mSv}$ of external exposure. Finally, radiation workers were cross classified according to external and internal exposures.

\section{STATISTICAL ANALYSIS}

Person years at risk were calculated from each worker's first day of employment at the Atomic Weapons Establishment or, because the study population was incomplete before 1951, from 1 January 1951 for workers recruited before that date. The date of exit from the study was taken as 31 December 1982 or the date of emigration, death, or the last date traced if any of these preceded 1 January 1983. Person years at risk and deaths were stratified by sex; age in 15 five year age groups ranging from $15-19$ to $\geqslant 85$; calendar year both in single years and in the seven periods 1951-4, 1955-9, 1960-4, 1965-9, 1970-4, 1975-9, and 1980-2; and social class (groups I, II, III non-manual, III manual, 
IV, and V). Additional stratification by years since recruitment, duration of employment, and calendar year of entry into the workforce was performed for certain analyses. For each stratum of radiation exposure person years at risk were calculated from the date when a subject first entered that stratum. In order to allow for latency between radiation exposure and its effect deaths and person years at risk were stratified in the same way as above, except that the exposures were lagged by two years for leukaemia and 10 years for other causes of death-that is, two and 10 years, respectively, were added to the year in which each yearly cumulative exposure occurred. Analyses were also performed lagging the exposures by five and 15 years.

All analyses were based on the underlying cause of death coded by the Office of Population Censuses and Surveys using the eighth revision of the ICD for 1951-78 and the ninth revision for 1979-82. Age, sex, and single year specific death rates for England and Wales were computed from data supplied by the Office of Population Censuses and Surveys using the same bridging codes as in the United Kingdom Atomic Energy Authority study. These were applied to the appropriate person years at risk to calculate expected deaths and standardised mortality ratios for each exposure group. Statistical significance of the standardised mortality ratios was assessed by using tables generated from the Poisson distribution ${ }^{19}$ or, when the number of observed deaths was greater than 200 , using an approximate standard normal deviate with continuity correction. Rate ratios adjusted for age, sex, calendar period, and social class were estimated to compare the mortality of different groups of workers without reference to national rates. These were obtained by the method of maximum likelihood using the GLIM (generalised linear interactive modelling) computer package, whereby the number of deaths in exposed workers in any stratum, conditional on the total number of deaths in that stratum, was assumed to follow the binomial distribution. The standard errors of the rate ratios generated from the maximum likelihood estimation procedure were used to obtain approximate $95 \%$ confidence limits. Significance of the rate ratios was tested by a $\chi^{2}$ statistic corrected for continuity. ${ }^{20}$ When the total number of deaths in the two groups was 20 or less exact confidence limits and significance levels were generated from the stratum specific deaths and person years by using the likelihood for binomial data.

For workers with a radiation record the relation between level of radiation exposure as classified in the five exposure categories and mortality was examined as in other studies in the United Kingdom. ${ }^{71011}$ Observed deaths in each dose category were compared with the number that would have been expected by assuming that within each stratum of age, sex, calendar period, and social class the death rate was the same regardless

\section{MINIPRINT TABLES I-III}
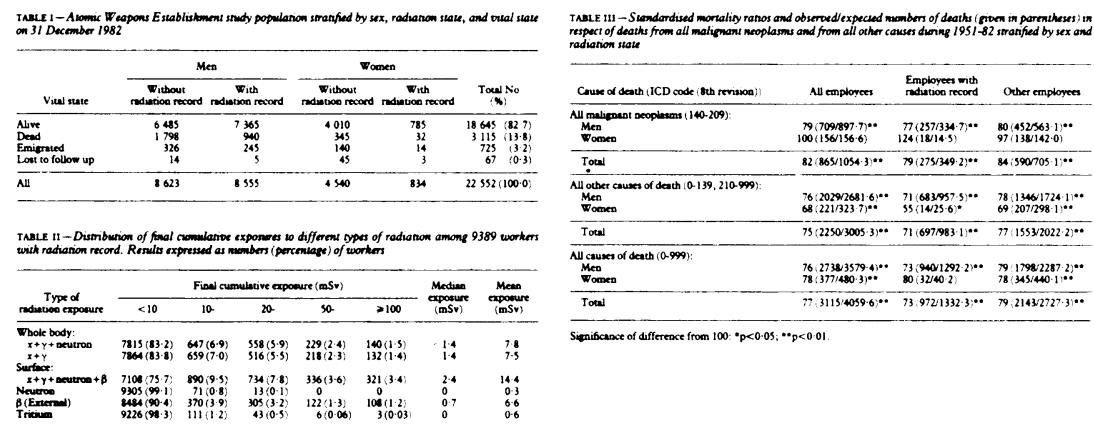

of dose. In lagged analyses people first exposed within 10 years (two years for leukaemia) of their date of exit from the study contributed person years at risk and deaths, but not exposures, to the lowest category of exposure. An overall $\chi^{2}$ statistic was obtained to test for a linear trend in cause specific death rates across levels of increasing exposure by pooling the stratum specific statistics in the appropriate manner. ${ }^{20}$ When the resultant test statistic was based on a total number of deaths of 20 or less probability values were checked by using 10000 simulations by randomly redistributing the deaths across the exposure categories in proportion to the person years at risk in each exposure category in each stratum.

The increase in relative risk per unit of exposure was estimated by using both multiplicative and additive models. Deaths and person years stratified by age, sex, calendar period, social class, and exposure category were used to fit the multiplicative model by means of standard Poisson regression procedures in GLIM. In order to fit the additive relative risk model directly using GLIM age, sex, and mortality rates for England and Wales specific for calendar period were used together with the deaths and person years similarly stratified by using the method described by Breslow and Day. ${ }^{20}$

Statistical significance was taken as $p<0.05$. Tests of statistical significance are quoted as two sided throughout. Comparisons of mortality from cancer with national rates were made for cancer at 28 specific anatomical sites and detailed analyses of cancer mortality in relation to radiation exposure at 14 specific anatomical sites, with some overlap among the different analyses. Some statistically significant results may therefore be expected to occur on the basis of chance alone. In interpreting the findings those for which similar results have not been described in other workforces were considered as being likely to be due to chance, except when the probability value was very low-that is, less than the $1 \%$ level. Where similar results have been described before attention is drawn to findings with a probability level of less than $5 \%$ in the expected direction.

\section{Results}

Table Im (miniprint) summarises the study population stratified by sex, radiation state, and vital state on 31 December 1982. Of the 22552 employees, $17178(76 \%)$ were men. There were 9389 employees $(42 \%)$ with a radiation record, of whom $8555(91 \%)$ were men. Subjects with a radiation record were followed up for an average of $18 \cdot 3$ years and subjects without a radiation record for an average of 18.8 years. A total of 3115 deaths ( $14 \%$ of the study population) had occurred by 31 December 1982. The death certificates disclosed that the cause of death had been confirmed by necropsy in 318 subjects (33\%) with radiation records and 616 subjects $(29 \%)$ without. There were 17 deaths for which the cause could not be ascertained. These were included in analyses of deaths from all causes but not in cause specific analyses. A total of 725 ex-employees (3\% of the study population) were reported to have emigrated by 31 December 1982. Of the $67(0.3 \%)$ ex-employees who were lost to follow up, only eight had a radiation record.

The collective external exposure in the Atomic Weapons Establishment study population was $73591 \mathrm{mSv}$ for whole body exposure and $135194 \mathrm{mSv}$ for surface exposure, giving average exposures of $7.8 \mathrm{mSv}$ and $14.4 \mathrm{mSv}$, respectively, per radiation worker. The distribution of exposure was, however, highly skewed (table IIm). Only 1574 (17\%) of the 9389 workers with a radiation record had a final cumulative whole body exposure of $10 \mathrm{mSv}$ or more, 
and only $140(1 \cdot 5 \%)$ had a cumulative exposure exceeding $100 \mathrm{mSv}$. The contribution of neutrons to whole body and surface exposure was small, fewer than $1 \%$ of workers having more than $10 \mathrm{mSv}$ of neutron irradiation recorded. The only measured internal exposure was that attributed to tritium, and the exposures were small compared with those from external radiation, fewer than $2 \%$ of workers having an exposure of $10 \mathrm{mSv}$ or more recorded.

\section{MORTALITY COMPARED WITH NATIONAL RATES:}

\section{STANDARDISED MORTALITY RATIOS}

Table IIIm shows the standardised mortality ratios for all causes of death and for deaths from malignant neoplasms and all other causes separately. Standardised mortality ratios of 77 for all causes and 82 for all cancers in the workforce as a whole were significantly lower than national rates $(p<0.01)$. This was in part due to the favourable location of the Atomic Weapons Establishment in south east England and the social class distribution of the workforce: 7293 workers (32\%) were classified as being in social class I or II compared with $21 \%$ nationally at ages 15 to $64 .{ }^{21}$ By using death rates for each social class in south east England for 1970-21 as a basis for calculating expected deaths the all cause standardised mortality ratio would have been 80 . There were no significant differences in the mortality of employees with and without a radiation record for any of the broad groupings of causes of death shown in table IIIm.

Standardised mortality ratios for all malignant neoplasms and all other causes of death were examined for workers with a radiation record and others separately stratified by years since recruitment, by duration of employment, and by calendar year of entry into the Atomic Weapons Establishment workforce (table IVm). There were no significant trends or differences in standardised mortality ratios for all malignant neoplasms across the levels of these variables for either group of workers. For causes of death other than cancer, standardised mortality ratios increased significantly with years since recruitment but decreased significantly the later the year of recruitment in employees with a radiation record and there was significant heterogeneity in the standardised mortality ratios according to duration of employment. When the trends in workers with a radiation record were compared with those in other workers the only significant difference was the trend by year of recruitment for non-malignant causes of death $(p=0 \cdot 04)$.

When standardised mortality ratios for specific causes of death in all employees were considered none was significantly greater than would be expected (table V). Indeed, in addition to the low standardised mortality ratio for all malignant neoplasms the standardised mortality ratios individually for cancers of the stomach, rectum, bronchus and lung, bladder

\section{MINIPRINT TABLE IV}

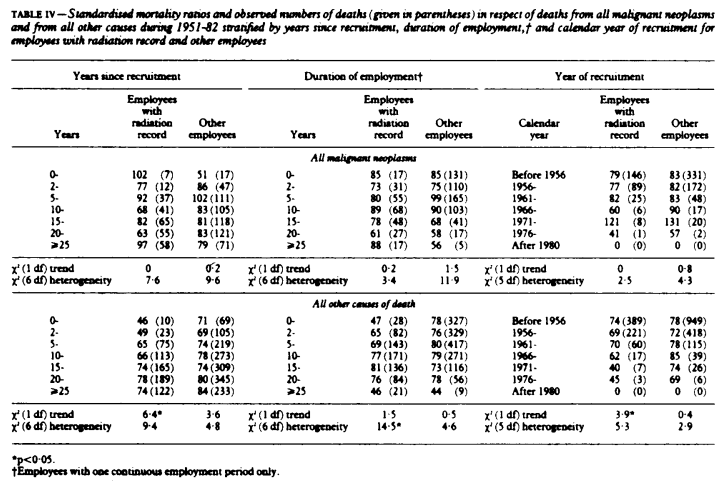

and other urinary organs, and cancers of ill defined and secondary sites were all significantly below 100 . So, too, were the standardised mortality ratios for benign and unspecified neoplasms, diseases of the nervous, circulatory, respiratory, digestive, and genitourinary systems, and accidents, suicide, and violence. Likewise for workers who had a radiation record the standardised mortality ratios for all malignant neoplasms, stomach, bronchus and lung, and brain cancers, diseases of the nervous, circulatory, respiratory, digestive, and genitourinary systems, and accidents, suicide, and violence were significantly below 100. There was no specific cause for which mortality was significantly greater than would be expected, but the standardised mortality ratio of 188 for cancer of the kidney in employees with a radiation record was of borderline significance $(p=0.07)$. Standardised mortality ratios of $\mathbf{4 4}$ for leukaemia, 56 for multiple myeloma, and 48 for all malignancies of the lymphatic and haemopoietic system in radiation workers were notably low, even though none was significantly below 100 . For employees without a radiation record no standardised mortality ratio was significantly greater than 100 . Significant deficits were apparent, however, for all malignant neoplasms, cancers of the stomach, rectum, and ill defined and secondary sites, and the main non-malignant causes of death shown in table $\mathrm{V}$.

MORTALITY OF EMPLOYEES WITH RADIATION RECORD COMPARED WITH OTHER EMPLOYEES: RATE RATIOS

When death rates for employees with a radiation record were compared with rates for other employees adjusting for age, sex, calendar period, and social class there were few significant differences (table V). The rate ratio for prostatic cancer in radiation workers compared with other employees was of borderline significance (rate ratio $1.90 ; p=0.07$ ), and for cancers of ill defined and secondary sites the twofold excess was significant (rate ratio $2.06 ; p=0.03$ ). Of the 47 employees certified as having died of cancer at an ill defined or secondary site, 31 had also been notified as having a cancer registration. In 24 of these (13 radiation workers, 11 others) the site of the primary lesion was also unknown at the time the cancer was registered but for the remaining seven (three radiation workers, four others) a specific cancer site was mentioned. For the three workers with a radiation record the cancers were registered as being primary tumours of the prostate, pancreas, and stomach; for the four other workers the primary sites were the lung (two cases), liver, and connective tissue. Had it been possible to attribute deaths in these workers to cancers of the more specific sites the significance of the rate ratios for all ill defined and secondary cancers would have persisted and that for prostatic cancer would have been strengthened.

None of the rate ratios was significantly below unity except that for all lymphatic and haemopoietic malignancies (rate ratio $0 \cdot 46 ; p=0.04$ ). The rate ratio for each specific type of lymphatic and haemopoietic malignancy was also below $1 \cdot 0$, though not significantly so, the rate ratio of 0.42 for leukaemia being one of the lowest. The four deaths attributed to leukaemia in workers with a radiation record were described on the death certificates as being due to acute myeloid leukaemia (two cases), acute lymphocytic leukaemia, and acute leukaemia; and the 16 deaths in other workers as being due to acute myeloid leukaemia (six cases), chronic myeloid leukaemia (two), acute lymphocytic leukaemia (two), chronic lymphocytic leukaemia (five), and acute leukaemia. After excluding employees with chronic lymphocytic leukaemia from the analyses the resultant rate ratio of 0.53 was still below $1 \cdot 0$, though not significantly so. Furthermore, 


\begin{tabular}{|c|c|c|c|c|c|}
\hline \multirow[b]{2}{*}{ Cause of death (ICD code ( 8 th revision)) } & \multirow[b]{2}{*}{ All employees } & \multirow{2}{*}{$\begin{array}{l}\text { Employees with } \\
\text { radiation record }\end{array}$} & \multirow[b]{2}{*}{ Other employees } & \multicolumn{2}{|c|}{$\begin{array}{l}\text { Rate ratio ( } 95 \% \text { confidence interval) for } \\
\text { employees with radiation record compared with } \\
\text { other employees with assumption of: }\end{array}$} \\
\hline & & & & No lag & 10 Year lag \\
\hline All malignant neoplasms (140-209) & $82(865 / 1054 \cdot 31) \star \star$ & $79(275 / 349 \cdot 20)^{\star \star}$ & $84(590 / 705 \cdot 11)^{\star \star}$ & $1.03(0.88$ to 1.20$)$ & $1.06(0.89$ to 1.27$)$ \\
\hline Buccal cavity and pharynx $(140-149)$ & $74(11 / 14.93)$ & $20(1 / 5.05)$ & $101(10 / 9 \cdot 88)$ & $0.22(0.01$ to 2.85$)$ & $0.31(0.01$ to 3.64$)$ \\
\hline Oesophagus $(150)$ & $111(31 / 27 \cdot 98)$ & $102(10 / 9 \cdot 85)$ & $116(21 / 18 \cdot 13)$ & $0.81(0.36$ to 1.81$)$ & $1.03(0.44$ to 2.39$)$ \\
\hline Stomach (151) & $71(77 / 108 \cdot 61)^{\star \star}$ & $67(24 / 35 \cdot 78)^{\star}$ & $73(53 / 72 \cdot 83)^{\star}$ & $0.98(0.59$ to 1.64$)$ & $1.01(0.55$ to 1.84$)$ \\
\hline Small intestine (152) & $96(2 / 2 \cdot 08)$ & $0(0 / 0 \cdot 70)$ & $145(2 / 1 \cdot 38)$ & $0.00(0.00$ to 5.99$)$ & $0.00(0.00$ to 16.39$)$ \\
\hline Large intestine (153) & $89(60 / 67 \cdot 55)$ & $108(23 / 21 \cdot 22)$ & $80(37 / 46 \cdot 33)$ & $1.27(0.72$ to 2.23$)$ & $0.92(0.46$ to 1.85$)$ \\
\hline $\operatorname{Rectum}(154)$ & $63(30 / 47 \cdot 37)^{\star \star}$ & $96(15 / 15 \cdot 55)$ & $47(15 / 31 \cdot 82)^{\star \star}$ & $2 \cdot 10(0.97$ to 4.52$)$ & $2.09(0.92$ to 4.75$)$ \\
\hline Liver $(155)$ & $80(4 / 5 \cdot 01)$ & $100(2 / 2 \cdot 00)$ & $66(2 / 3 \cdot 01)$ & $1 \cdot 23(0 \cdot 10$ to $15 \cdot 10)$ & $1.37(0.02$ to $24 \cdot 13)$ \\
\hline Gall bladder (156) & $77(4 / 5 \cdot 21)$ & $0(0 / 1 \cdot 76)$ & $116(4 / 3 \cdot 45)$ & $0.00(0.00$ to 3.27$)$ & $0.00(0.00$ to 4.23$)$ \\
\hline Pancreas (157) & $77(34 / 43.94)$ & $100(15 / 14 \cdot 99)$ & $66(19 / 28 \cdot 95)$ & $1.50(0.72$ to 3.11$)$ & $1.24(0.54$ to 2.84$)$ \\
\hline Nasal cavities and sinuses $(160)$ & $90(2 / 2 \cdot 23)$ & $260(2 / 0 \cdot 77)$ & $0(0 / 1 \cdot 46)$ & $x(0.25$ to $x)$ & $0.00(0.00$ to 503.8$)$ \\
\hline Larynx (161) & $110(10 / 9 \cdot 12)$ & $125(4 / 3 \cdot 19)$ & $101(6 / 5.93)$ & $0.91(0.21$ to 3.96$)$ & $0.92(0.07$ to 11.96$)$ \\
\hline Bronchus and lung (162) & $82(294 / 358 \cdot 71) \star \star$ & $64(85 / 132 \cdot 86)^{\star \star}$ & $93(209 / 225 \cdot 85)$ & $0.84(0.64$ to 1.09$)$ & $0.84(0.61$ to 1.15$)$ \\
\hline Bone (170) & $24(1 / 4 \cdot 09)$ & $74(1 / 1 \cdot 35)$ & $0(0 / 2 \cdot 74)$ & $x(0.03$ to $x)$ & $\infty(0.12$ to $\infty)$ \\
\hline Melanoma and other skin (172-173) & $53(5 / 9 \cdot 46)$ & $62(2 / 3 \cdot 24)$ & $48(3 / 6 \cdot 22)$ & $2.19(0.27$ to 18.02$)$ & $1.36(0.02$ to 43.30$)$ \\
\hline Breast (174) & $110(44 / 40 \cdot 10)$ & $142(6 / 4 \cdot 21)$ & $106(38 / 35 \cdot 89)$ & $1.36(0.55$ to 3.34$)$ & $1.51(0.51$ to 4.46$)$ \\
\hline Uterus $(180-182)$ & $91(12 / 13 \cdot 13)$ & $165(2 / 1 \cdot 21)$ & $84(10 / 11 \cdot 92)$ & $3.82(0.36$ to 37.60$)$ & $3 \cdot 10(0.06$ to $51 \cdot 66)$ \\
\hline Ovary (183) & $101(13 / 12.90)$ & $81(1 / 1 \cdot 24)$ & $103(12 / 11 \cdot 66)$ & $0.92(0.14$ to $14 \cdot 77)$ & $0.00(0.00$ to 40.81$)$ \\
\hline Prostate (185) & $99(43 / 43 \cdot 50)$ & $139(20 / 14 \cdot 36)$ & $79(23 / 29 \cdot 14)$ & $1.90(1.00$ to 3.62$)$ & $2 \cdot 23(1 \cdot 13 \text { to } 4 \cdot 40)^{\star}$ \\
\hline Testis (186) & $50(2 / 4 \cdot 01)$ & $58(1 / 1 \cdot 72)$ & $44(1 / 2 \cdot 29)$ & $0.93(0.01$ to 88.95$)$ & $4.61(0.02$ to 1032.2$)$ \\
\hline Bladder and other urinary (188-189 except $189 \cdot 0)$ & $68(28 / 41 \cdot 33)^{\star}$ & $51(7 / 13 \cdot 69)$ & $76(21 / 27 \cdot 64)$ & $0.69(0.28$ to 1.70$)$ & $0.70(0.25$ to 1.98$)$ \\
\hline Kidney $(189 \cdot 0)$ & $136(22 / 16 \cdot 18)$ & $188(11 / 5 \cdot 84)$ & $106(11 / 10 \cdot 34)$ & $1.71(0.69$ to 4.23$)$ & $2.39(0.94$ to 6.09$)$ \\
\hline Brain and other central nervous system $(191-192)$ & $75(19 / 25 \cdot 46)$ & $32(3 / 9 \cdot 36)^{\star}$ & $99(16 / 16 \cdot 10)$ & $0.32(0.10$ to $2 \cdot 20)$ & $0.00(0.00$ to 5.07$)$ \\
\hline Thyroid (193) & $132(3 / 2 \cdot 28)$ & $300(2 / 0.67)$ & $62(1 / 1.61)$ & $7 \cdot 40(0 \cdot 16$ to $673 \cdot 7)$ & $11 \cdot 05(0.22$ to $1311 \cdot 8)$ \\
\hline III defined and secondary (195-199) & $67(47 / 70 \cdot 26)^{\star \star}$ & $108(23 / 21 \cdot 22)$ & $49(24 / 49 \cdot 04)^{\star \star}$ & $2.06(1.11$ to 3.81$)$ & $2.37(1.23 \text { to } 4.56)^{\star}$ \\
\hline All lymphatic and haemopoietic (200-209) & $82(54 / 65 \cdot 74)$ & $48(11 / 22 \cdot 92)$ & $100(43 / 42 \cdot 82)$ & $0.46(0.23 \text { to } 0.94)^{\star}$ & $0.57(0.25$ to 1.29$)$ \\
\hline Non-Hodgkin's lymphoma $(200,202)$ & $87(15 / 17 \cdot 23)$ & $49(3 / 6 \cdot 17)$ & $109(12 / 11 \cdot 06)$ & $0.53(0.10$ to $5 \cdot 03)$ & $0.90(0 \cdot 16$ to $12 \cdot 43)$ \\
\hline Hodgkin's disease (201) & $71(7 / 9 \cdot 82)$ & $56(2 / 3 \cdot 55)$ & $80(5 / 6 \cdot 26)$ & $0.57(0.11$ to 2.63$)$ & $0.50(0.06$ to 3.20$)$ \\
\hline Multiple myeloma (203) & $87(9 / 10 \cdot 32)$ & $56(2 / 3.55)$ & $103(7 / 6 \cdot 77)$ & $0.62(0.05$ to 7.47$)$ & $0.97(0.07$ to 11.33$)$ \\
\hline Leukaemia (204-208) & $74(20 / 26 \cdot 95)$ & $44(4 / 9 \cdot 16)$ & $90(16 / 17 \cdot 78)$ & $0.42(0.15$ to 2.44$)$ & $0.38(0.08$ to 3.36$) \dagger$ \\
\hline All benign and unspecified neoplasms $(210-239)$ & $40(5 / 12 \cdot 36)^{\star}$ & $25(1 / 4 \cdot 03)$ & $48(4 / 8 \cdot 33)$ & $0.64(0.03$ to 5.82$)$ & $0.97(0.03$ to 17.23$)$ \\
\hline Brain and nervous system $(225,238)$ & $38(3 / 7 \cdot 84)$ & $38(1 / 2 \cdot 62)$ & $38(2 / 5 \cdot 21)$ & $0.98(0.03$ to 14.76$)$ & $0.00(0.00$ to 54.97$)$ \\
\hline All diseases of blood (280-289) & $38(3 / 7 \cdot 91)$ & $0(0 / 2 \cdot 25)$ & $53(3 / 5 \cdot 66)$ & $0.00(0.00$ to 8.14$)$ & $0.00(0.00$ to 28.26$)$ \\
\hline All diseases of nervous system $(320-389)$ & $53(25 / 47 \cdot 55)^{\star \star}$ & $39(6 / 15 \cdot 59)^{\star}$ & $59(19 / 31 \cdot 97)^{\star}$ & $0.68(0.25$ to 1.83$)$ & $0.93(0.31$ to $2 \cdot 78)$ \\
\hline All diseases of circulatory system (390-458) & $81(1565 / 1938 \cdot 25)^{\star \star}$ & $80(517 / 643.05)^{\star \star}$ & $81(1048 / 1295 \cdot 20)^{\star \star}$ & $1.01(0.90$ to 1.13$)$ & $1.06(0.94$ to 1.20$)$ \\
\hline All diseases of respiratory system $(460-519)$ & $62(322 / 516 \cdot 81)^{\star \star}$ & $58(91 / 158 \cdot 0)^{\star}$ & $64(231 / 358 \cdot 80)^{\star \star}$ & $0.94(0.73$ to 1.22$)$ & $0.87(0.65$ to 1.17$)$ \\
\hline All diseases of digestive system $(520-577)$ & $58(62 / 106 \cdot 08)^{\star \star}$ & $32(11 / 33.95) \star \star$ & $72(51 / 71 \cdot 13)^{\star}$ & $0.51(0.26$ to 1.01$)$ & $0.47(0.20$ to 1.07$)$ \\
\hline All diseases of genitourinary system (580-629) & $60(35 / 58 \cdot 15)^{\star \star}$ & $47(8 / 17 \cdot 05)^{\star}$ & $66(27 / 41 \cdot 10)^{\star}$ & $0.77(0.33$ to 1.79$)$ & $1.25(0.50$ to 3.13$)$ \\
\hline Hyperplasia of prostate $(600)$ & $51(5 / 9 \cdot 75)$ & $117(3 / 2 \cdot 56)$ & $28(2 / 7 \cdot 19)$ & $4.65(0.42$ to 174.4$)$ & $8.59(0.46$ to 502.0$)$ \\
\hline Accidents, suicide, and violence $(800-999)$ & $75(151 / 202 \cdot 24)^{\star \star}$ & $65(48 / 74 \cdot 31)^{\star \star}$ & $81(103 / 127 \cdot 93)^{\star}$ & $0.84(0.58$ to 1.21$)$ & $0.77(0.45$ to 1.30$)$ \\
\hline $\operatorname{ses}(0$ & $77(3115 / 4059 \cdot 65)^{\star \star}$ & $73(972 / 1332 \cdot 33) \star \star$ & $79(2143 / 2727 \cdot 32)^{\star \star}$ & $0.96(0.89$ to 1.05$)$ & $1.01(0.92$ to $1 \cdot 10)$ \\
\hline
\end{tabular}

Significance of difference from 100 (standardised mortality ratios) or 1 (rate ratios): ${ }^{\star} \mathrm{p}<0.05 ;{ }^{\star \star} \mathrm{p}<0.01$

had data on associated causes of death and from cancer registrations been used to supplement this information the findings would not have altered; two more employees with leukaemia were thus identified among those with a radiation record (chronic myeloid leukaemia and chronic lymphocytic leukaemia) and five more among the other workers (chronic lymphocytic leukaemia (four cases) and acute leukaemia).

Cancers induced by radiation (except leukaemia) tend not to occur until at least 10 years after exposure, ${ }^{22}$ so that exposures received in the years immediately preceding death may be less relevant than earlier exposures. Standardised mortality ratios and rate ratios were therefore recalculated lagging exposure by two years for leukaemia and 10 years for other causes of death. Table $\mathrm{V}$ gives the corresponding rate ratios, those for prostatic cancer and cancers of ill defined and secondary sites being significantly in excess of 1.0 (rate ratio $2.23, \mathrm{p}=0.03$; rate ratio $2.37, \mathrm{p}=0.01$, respectively). In the employees with a radiation record the corresponding standardised mortality ratios (not shown in table V) were 158 for prostatic cancer (18 deaths) and 164 for cancers of ill defined and secondary sites ( 19 deaths). The excess mortality from prostatic cancer in radiation workers was more pronounced in younger than older men, the ratio of the standardised mortality ratios being 3.8 at ages less than 65 and 1.8 at older ages. In workers with a radiation record the standardised mortality ratio for renal cancer, after lagging exposure by 10 years, was significantly greater than expectation on the basis of national rates (standardised mortality ratio 253 based on 10 deaths; $p=0.02)$; the corresponding rate ratio of 2.39 was of borderline significance $(p=0.07)$. The raised rate ratios and standardised mortality ratios for thyroid cancer allowing for a $\mathbf{1 0}$ year lag (rate ratio $11 \cdot 05$, standardised mortality ratio 458 , based on two deaths) and hyperplasia of the prostate (rate ratio 8.59 , standardised mortality ratio 164 , based on three deaths), though not statistically significant, were of relevance in the context of other studies. ${ }^{70}$ For no condition was there a significant deficit in the mortality of workers with a radiation record compared with other employees. For each specific malignancy of the lymphatic and haemopoietic system, and all of these sites combined, the rate ratio was consistently but not significantly below $1 \cdot 0$.

\section{MORTALITY AND LEVEL OF CUMULATIVE EXTERNAL} RADIATION EXPOSURE

Table VI shows mortality from selected causes of death among workers with a radiation record stratified by cumulative whole body exposure to external radiation after adjusting for age, sex, calendar period, and social class, without lagging exposure. Specific cancer sites were selected when there were at least 10 deaths in radiation workers or when prior evidence suggested excess mortality in exposed workers. ${ }^{1-14}$ There were no significant trends in mortality with increasing exposure, though for all malignant neoplasms there was a weak trend of increasing mortality as exposure increased. None of the deaths attributed to leukaemia or multiple myeloma occurred in employees who had a recorded cumulative whole body exposure of $10 \mathrm{mSv}$ or more, and for all haemopoietic and lymphatic neoplasms mortality declined with increasing exposure. For causes of death other than malignant neoplasms mortality increased with increasing exposure, the trend being of 
borderline significance $(p=0.08)$. Examination of broad groupings of causes of death showed that the main contribution came from accidental and violent causes. Of the six deaths from these causes in workers with cumulative exposures of $50 \mathrm{mSv}$ or more, two were attributed to road traffic accidents, two to suicide, and two to accidental poisoning. For other causes of death there was no evidence of an association between exposure and mortality.

Analyses similar to those in table VI were carried out lagging the exposure by two years for leukaemia and 10 years for other causes of death (table VII). With a 10 year lag mortality from all malignant neoplasms and from bronchial and lung cancer increased significantly as cumulative exposure increased $(p=0.04$ and $p=0.001$, respectively). The trend for all causes of death was significant also $(p=0.02)$ and was largely due to the trend for deaths from cancer. Though dependent on one death in the highest exposure category, mortality from prostatic cancer increased with increasing exposure, the corresponding probability values being $0 \cdot 18$ with the approximate $\chi^{2}$ test for trend and $0 \cdot 10$ based on 10000 simulations (1031/10000). For other causes of death the simulated probability values agreed well with those derived from the $\chi^{2}$ test for trend. The trend for all non-malignant causes of death was not significant but that for diseases of the respiratory system was $(p=0 \cdot 006)$. Analyses of the type shown in tables VI and VII were repeated for surface exposure and for $x$ plus $\gamma$ radiation alone-that is, excluding the neutron component from whole body exposure-and essentially similar results were obtained. The analyses were also repeated incorporating lags of five and 15 years. With a five year lag no significant trends were found. With a 15 year lag the relative excesses of all cancer and lung cancer in the higher exposure categories were larger than when a 10 year lag was assumed but the numbers of deaths were smaller and the level of significance declined to $p=0.08$ for all cancers and $p=0.01$ for lung cancer.

TABLE VI-Relation of mortality from selected causes of death to cumulative whole body exposure adjusted for age, sex, calendar period, and social class. Results expressed as ratio of observed to expected numbers of deaths (observedlexpected numbers given in parentheses; expected numbers based on rates in all subjects with radiation record)

\begin{tabular}{|c|c|c|c|c|c|c|c|}
\hline \multirow[b]{2}{*}{ Cause of death (ICD code ( 8 th revision)) } & \multicolumn{5}{|c|}{ Cumulative whole body exposure (mSv) } & \multirow{2}{*}{$\begin{array}{l}\text { Total } \\
\text { deaths }\end{array}$} & \multirow{2}{*}{$\begin{array}{c}\chi^{2} \text { Test } \\
\text { for trend on } 1 \mathrm{df} \\
\text { (direction of trend) }\end{array}$} \\
\hline & $<10$ & $10-$ & 20- & $50-$ & $\geqslant 100$ & & \\
\hline All malignant neoplasms $(140-209)$ & $0.98(223 / 227 \cdot 75)$ & $1 \cdot 20(23 / 19 \cdot 17)$ & $0.95(17 / 17.94)$ & $1 \cdot 27(8 / 6 \cdot 28)$ & $1.04(4 / 3 \cdot 86)$ & 275 & $0.22(+)$ \\
\hline Oesophagus $(150)$ & $0.86(7 / 8 \cdot 11)$ & $3.95(3 / 0 \cdot 76)$ & $0(0 / 0.64)$ & $0(0 / 0 \cdot 28)$ & $0(0 / 0 \cdot 21)$ & 10 & $0.26(-)$ \\
\hline Stomach $(151)$ & $0 \cdot 99(20 / 20 \cdot 21)$ & $2 \cdot 12(3 / 1 \cdot 42)$ & $0.62(1 / 1 \cdot 61)$ & $0(0 / 0 \cdot 49)$ & $0(0 / 0 \cdot 28)$ & 24 & $0.57(-)$ \\
\hline Large intestine (153) & $0.99(18 / 18 \cdot 16)$ & $2.08(4 / 1.92)$ & $0(0 / 1 \cdot 86)$ & $1.48(1 / 0 \cdot 68)$ & $0(0 / 0.39)$ & 23 & $0 \cdot 34(-)$ \\
\hline $\operatorname{Rectum}(154)$ & $0.91(11 / 12.04)$ & $0.76(1 / 1.32)$ & $2.76(3 / 1.09)$ & $0(0 / 0 \cdot 35)$ & $0(0 / 0 \cdot 21)$ & 15 & $0 \quad(-)$ \\
\hline Pancreas (157) & $0 \cdot 90(11 / 12 \cdot 22)$ & $2 \cdot 57(3 / 1 \cdot 17)$ & $1.06(1 / 0.94)$ & $0(0 / 0 \cdot 43)$ & $0(0 / 0 \cdot 23)$ & 15 & $0 \cdot 20(-)$ \\
\hline Bronchus and lung (162) & $1.00(71 / 71 \cdot 07)$ & $0.36(2 / 5.53)$ & $0.93(5 / 5 \cdot 36)$ & $2 \cdot 81(5 / 1 \cdot 78)$ & $1.58(2 / 1.27)$ & 85 & $1.96(+)$ \\
\hline Prostate (185) & $0.93(15 / 16 \cdot 11)$ & $0.70(1 / 1 \cdot 42)$ & $1.35(2 / 1.48)$ & $1.60(1 / 0.63)$ & $2 \cdot 80(1 / 0 \cdot 36)$ & 20 & $1.62(+)$ \\
\hline Bladder and other urinary (188-189 except $189 \cdot 0)$ & $1.01(6 / 5.97)$ & $0(0 / 0 \cdot 45)$ & $2 \cdot 72(1 / 0 \cdot 37)$ & $0(0 / 0 \cdot 13)$ & $0(0 / 0 \cdot 08)$ & 7 & $0.03(-)$ \\
\hline Kidney $(189.0)$ & $0.91(8 / 8.78)$ & $0(0 / 0 \cdot 77)$ & $2 \cdot 13(2 / 0.94)$ & $3.06(1 / 0 \cdot 33)$ & $0(0 / 0 \cdot 20)$ & 11 & $0 \cdot 24(+)$ \\
\hline Brain and nervous system $(191-192,225,238) \dagger$ & $1.09(4 / 3.66)$ & $0(0 / 0 \cdot 12)$ & $0(0 / 0 \cdot 15)$ & $0(0 / 0 \cdot 06)$ & $0(0 / 0.01)$ & 4 & $0.22(-)$ \\
\hline Ill defined and secondary $(195-199)$ & $0.98(19 / 19 \cdot 40)$ & $1.30(2 / 1.54)$ & $0.76(1 / 1 \cdot 31)$ & $0(0 / 0 \cdot 48)$ & $3 \cdot 66(1 / 0 \cdot 27)$ & 23 & $0.62(+)$ \\
\hline All lymphatic and haemopoietic (200-209) & $1 \cdot 01(9 / 8 \cdot 88)$ & $1.17(1 / 0.86)$ & $1 \cdot 24(1 / 0 \cdot 81)$ & $0(0 / 0 \cdot 30)$ & $0(0 / 0 \cdot 15)$ & 11 & $0.25(-)$ \\
\hline Non-Hodgkin's lymphoma $(200,202)$ & $0.83(2 / 2 \cdot 41)$ & $3 \cdot 85(1 / 0 \cdot 26)$ & $0(0 / 0 \cdot 23)$ & $0(0 / 0 \cdot 08)$ & $0(0 / 0.02)$ & 3 & $0.03(-)$ \\
\hline Multiple myeloma (203) & $1 \cdot 25(2 / 1 \cdot 61)$ & $0(0 / 0 \cdot 15)$ & $0(0 / 0 \cdot 17)$ & $0(0 / 0 \cdot 04)$ & $0(0 / 0 \cdot 03)$ & 2 & $0 \cdot 23(-)$ \\
\hline Leukaemia (204-208) & $1 \cdot 25(4 / 3.20)$ & $0(0 / 0 \cdot 31)$ & $0(0 / 0 \cdot 26)$ & $0(0 / 0 \cdot 14)$ & $0(0 / 0.09)$ & 4 & $0.48(-)$ \\
\hline All causes except malignant neoplasms $(0-139,210-999)$ & $0.99(569 / 575.85)$ & $0.95(48 / 50.47)$ & $1 \cdot 02(46 / 45 \cdot 32)$ & $1 \cdot 26(21 / 16 \cdot 67)$ & $1.50(13 / 8.68)$ & 697 & $3 \cdot 08(+)$ \\
\hline All diseases of circulatory system $(390-458)$ & $1.00(423 / 424.49)$ & $0.94(36 / 38.52)$ & $1.07(37 / 34.55)$ & $0.94(12 / 12 \cdot 78)$ & $1.35(9 / 6 \cdot 66)$ & 517 & $0.53(+)$ \\
\hline All diseases of respiratory system $(460-519)$ & $0.95(74 / 77 \cdot 65)$ & $1 \cdot 27(7 / 5 \cdot 53)$ & $1.01(5 / 4.95)$ & $1.54(3 / 1.95)$ & $2 \cdot 16(2 / 0.93)$ & 91 & $2 \cdot 09(+)$ \\
\hline Accidents, suicide, and violence (800-999) & $0.88(35 / 39 \cdot 66)$ & $1 \cdot 12(4 / 3 \cdot 57)$ & $0.97(3 / 3.09)$ & $3.66(4 / 1.09)$ & $3.36(2 / 0 \cdot 60)$ & 48 & $9 \cdot 02(+)^{\star \star}$ \\
\hline All causes $(0-999)$ & $0.99(792 / 803 \cdot 60)$ & $1.02(71 / 69 \cdot 65)$ & $1 \cdot 00(63 / 63 \cdot 26)$ & $1 \cdot 26(29 / 22 \cdot 95)$ & $1 \cdot 36(17 / 12 \cdot 54)$ & 972 & $2.99(+)$ \\
\hline $\begin{array}{l}\text { Person years at risk } \\
\text { Median cumulative exposure (mSv) }\end{array}$ & $\begin{array}{c}122764 \\
0.93\end{array}$ & $\begin{array}{l}9676 \\
13.92\end{array}$ & $\begin{array}{l}8408 \\
29 \cdot 17\end{array}$ & $\begin{array}{l}3121 \\
65 \cdot 94\end{array}$ & $\begin{array}{c}1746 \\
144 \cdot 74\end{array}$ & & \\
\hline
\end{tabular}

${ }^{\star \star} \mathrm{p}<0 \cdot 01$.

tIncludes benign and unspecified neoplasms of nervous system.

TABLE VII-Relation of mortality from selected causes of death to cumulative whole body exposure lagging exposures by two years for leukaemia and 10 years for all other causes of death, adjusted for age, sex, calendar period, and social class. Results expressed as ratio of observed to expected numbers of deaths (observed/expected numbers given in parentheses; expected numbers based on rates in all subjects with radiation record)

\begin{tabular}{|c|c|c|c|c|c|c|c|}
\hline \multirow[b]{2}{*}{ Cause of death (ICD code (8th revision)) } & \multicolumn{5}{|c|}{ Cumulative whole body exposure (mSv) } & \multirow{2}{*}{$\begin{array}{l}\text { Total } \\
\text { deaths }\end{array}$} & \multirow{2}{*}{$\begin{array}{c}\chi^{2} \text { Test } \\
\text { for trend on } 1 \mathrm{df} \\
\text { (direction of trend) }\end{array}$} \\
\hline & $<10$ & $10-$ & $20-$ & $50-$ & $\geqslant 100$ & & \\
\hline All malignant neoplasms $(140-209)$ & $0.96(239 / 249 \cdot 62)$ & $1 \cdot 53(18 / 11 \cdot 78)$ & $1 \cdot 14(11 / 9 \cdot 64)$ & $1.59(4 / 2.52)$ & $2.09(3 / 1.43)$ & 275 & $4 \cdot 37(+)^{\star}$ \\
\hline Oesophagus $(150)$ & $0.79(7 / 8 \cdot 85)$ & $6.09(3 / 0.49)$ & $0(0 / 0.43)$ & $0(0 / 0 \cdot 18)$ & $0(0 / 0.05)$ & 10 & $0.01(+)$ \\
\hline Stomach $(151)$ & $1.00(22 / 21.94)$ & $2 \cdot 27(2 / 0 \cdot 88)$ & $0(0 / 0.85)$ & $0(0 / 0 \cdot 23)$ & $0(0 / 0 \cdot 10)$ & 24 & $0.43(-)$ \\
\hline Large intestine (153) & $0.99(20 / 20.25)$ & $1.51(2 / 1.33)$ & $0(0 / 0.99)$ & $3.47(1 / 0 \cdot 29)$ & $0(0 / 0 \cdot 15)$ & 23 & $0.01(-)$ \\
\hline $\operatorname{Rectum}(154)$ & $0.89(12 / 13.48)$ & $2.68(2 / 0 \cdot 75)$ & $1.75(1 / 0.57)$ & $0(0 / 0 \cdot 13)$ & $0(0 / 0.07)$ & 15 & $0.06(+)$ \\
\hline Pancreas (157) & $0 \cdot 87(12 / 13 \cdot 81)$ & $3 \cdot 20(2 / 0 \cdot 62)$ & $2 \cdot 36(1 / 0 \cdot 42)$ & $0(0 / 0.09)$ & $0(0 / 0 \cdot 06)$ & 15 & $0 \cdot 27(+)$ \\
\hline Bronchus and lung (162) & $0.94(73 / 77 \cdot 86)$ & $0.61(2 / 3 \cdot 30)$ & $2 \cdot 27(6 / 2 \cdot 65)$ & $2 \cdot 75(2 / 0 \cdot 73)$ & $4 \cdot 35(2 / 0 \cdot 46)$ & 85 & $10.66(+)^{\star \star}$ \\
\hline Prostate (185) & $0.99(17 / 17 \cdot 20)$ & $0.79(1 / 1.27)$ & $0.95(1 / 1.05)$ & $0(0 / 0 \cdot 35)$ & $7 \cdot 52(1 / 0 \cdot 13)$ & 20 & $1.80(+)$ \\
\hline Bladder and other urinary (188-189 except $189 \cdot 0)$ & $0.93(6 / 6.44)$ & $0(0 / 0 \cdot 28)$ & $5 \cdot 32(1 / 0 \cdot 19)$ & $0(0 / 0.04)$ & $0(0 / 0 \cdot 05)$ & 7 & $0 \cdot 10(+)$ \\
\hline Kidney $(189 \cdot 0)$ & $0.93(9 / 9.67)$ & $1.89(1 / 0.53)$ & $1.70(1 / 0.59)$ & $0(0 / 0 \cdot 12)$ & $0(0 / 0 \cdot 09)$ & 11 & $0 \quad(-)$ \\
\hline Brain and nervous system $(191-192,225,238) \dagger$ & $1.02(4 / 3.93)$ & $0(0 / 0.06)$ & $0(0 / 0 \cdot 00)$ & $0(0 / 0 \cdot 00)$ & $0(0 / 0 \cdot 00)$ & 4 & $0.03(-)$ \\
\hline Ill defined and secondary (195-199) & $0.95(20 / 21 \cdot 16)$ & $2 \cdot 21(2 / 0 \cdot 90)$ & $0(0 / 0 \cdot 71)$ & $6.79(1 / 0 \cdot 15)$ & $0(0 / 0 \cdot 08)$ & 23 & $0.56(-)$ \\
\hline All lymphatic and haemopoietic (200-209) & $1.03(10 / 9 \cdot 74)$ & $1.71(1 / 0.59)$ & $0(0 / 0 \cdot 45)$ & $0(0 / 0 \cdot 12)$ & $0(0 / 0 \cdot 10)$ & 11 & $0.32(-)$ \\
\hline Non-Hodgkin's lymphoma $(200,202)$ & $0.75(2 / 2.65)$ & $5 \cdot 55(1 / 0 \cdot 18)$ & $0(0 / 0 \cdot 12)$ & $0(0 / 0 \cdot 03)$ & $0(0 / 0 \cdot 01)$ & 3 & $0.04(+)$ \\
\hline Multiple myeloma (203) & $1 \cdot 14(2 / 1 \cdot 75)$ & $0(0 / 0 \cdot 12)$ & $0(0 / 0 \cdot 10)$ & $0(0 / 0 \cdot 01)$ & $0(0 / 0 \cdot 02)$ & 2 & $0 \cdot 12(-)$ \\
\hline Leukaemia (204-208) & $1 \cdot 24(4 / 3 \cdot 22)$ & $0(0 / 0 \cdot 28)$ & $0(0 / 0 \cdot 26)$ & $0(0 / 0 \cdot 14)$ & $0(0 / 0 \cdot 09)$ & 4 & $0.47(-)$ \\
\hline All causes except malignant neoplasms $(0-139,210-999)$ & $0.99(623 / 629 \cdot 5)$ & $0.91(29 / 31 \cdot 75)$ & $1 \cdot 25(31 / 24 \cdot 79)$ & $1 \cdot 22(10 / 8 \cdot 18)$ & $1 \cdot 45(4 / 2 \cdot 76)$ & 697 & $1.83(+)$ \\
\hline All diseases of circulatory system $(390-458)$ & $1.00(465 / 465.01)$ & $0.97(24 / 24.65)$ & $1 \cdot 15(22 / 19 \cdot 06)$ & $0.49(3 / 6 \cdot 17)$ & $1 \cdot 42(3 / 2 \cdot 11)$ & 517 & $0 \quad(-)$ \\
\hline All diseases of respiratory system $(460-519)$ & $0.93(77 / 82.63)$ & $1 \cdot 31(5 / 3 \cdot 81)$ & $1 \cdot 56(5 / 3 \cdot 21)$ & $2 \cdot 72(3 / 1 \cdot 11)$ & $4.04(1 / 0 \cdot 25)$ & 91 & $7 \cdot 59(+)^{\star \star}$ \\
\hline Accidents, suicide, and violence $(800-999)$ & $0.97(43 / 44 \cdot 53)$ & $0(0 / 1 \cdot 54)$ & $2 \cdot 52(3 / 1 \cdot 19)$ & $3.75(2 / 0.53)$ & $0(0 / 0 \cdot 21)$ & 48 & $1 \cdot 44(+)$ \\
\hline All causes $(0-999)$ & $0.98(862 / 879 \cdot 15)$ & $1 \cdot 08(47 / 43 \cdot 54)$ & $1 \cdot 22(42 / 34 \cdot 43)$ & $1 \cdot 31(14 / 10 \cdot 70)$ & $1 \cdot 67(7 / 4 \cdot 20)$ & 972 & $5 \cdot 16(+)^{\star}$ \\
\hline $\begin{array}{l}\text { Person years at risk } \\
\text { Median cumulative exposure (mSv) }\end{array}$ & $\begin{array}{c}136366 \\
0.72\end{array}$ & $\begin{array}{l}4285 \\
13.90\end{array}$ & $\begin{array}{l}3409 \\
28.98\end{array}$ & $\begin{array}{l}1100 \\
65 \cdot 74\end{array}$ & $\begin{array}{c}555 \\
134 \cdot 53\end{array}$ & & \\
\hline
\end{tabular}


The significance of the trend for prostatic cancer was strengthened to $p=0.07$ when a 15 year lag was assumed. The findings with a 15 year lag were generally similar for whole body and surface exposure. For bladder cancer, however, there was a statistically significant trend with surface exposure but not for whole body exposure. One death attributed to bladder cancer in the highest exposure category where only 0.095 death was expected largely accounted for this finding $\left(\chi^{2}\right.$ for trend $\left.=6.47 ; p=0.01\right)$.

Table VIII summarises the findings for mortality from all malignant neoplasms and all other causes of death for different types of exposure to external radiation and different lag periods. In the upper part of the table rate ratios are presented for workers who accumulated $10 \mathrm{mSv}$ or more of whole body, surface, and $x$ plus $\gamma$ ray exposure compared with the monitored workers who accumulated less than $10 \mathrm{mSv}$.

TABLE VIII - Rate ratios for all malignant neoplasms (ICD codes 140-209) and all other causes of death (ICD codes 0-139, 210-999) in workers accumulating specified exposures compared with other workers with radiation record, according to type of radiation exposure and latency (observed numbers of deaths in numerator given in parentheses). Rate ratios adjusted for age, sex, calendar period, and social class

\begin{tabular}{|c|c|c|c|c|c|c|}
\hline \multirow{2}{*}{$\begin{array}{c}\text { Type of } \\
\text { radiation exposure }\end{array}$} & \multirow{2}{*}{$\begin{array}{c}\text { Cause of } \\
\text { death }\end{array}$} & \multicolumn{5}{|c|}{ Rate ratio lagging exposures by: } \\
\hline & & 0 Year & 5 Years & 10 Years & 15 Yea & ears \\
\hline \multicolumn{7}{|c|}{ Workers with cumulative exposures of $\geqslant 10 \mathrm{mSv}$ compared with other workers with radiation record } \\
\hline $\begin{array}{l}\text { Whole body: } \\
x+\gamma+\text { neutron }\end{array}$ & $\left\{\begin{array}{l}\text { All malignant neoplasms } \\
\text { All other causes of death }\end{array}\right.$ & $\begin{array}{lr}1.13 & (52) \\
1.07 & (128)\end{array}$ & $\begin{array}{l}1.22(44) \\
1.09(105)\end{array}$ & $\begin{array}{ll}1.54^{\star} & (36) \\
1 \cdot 12 & (74)\end{array}$ & $\begin{array}{l}1.65^{\star} \\
1.36\end{array}$ & $\begin{array}{l}(20) \\
(44)\end{array}$ \\
\hline $\begin{array}{c}x+\gamma \\
\text { Surface: }\end{array}$ & $\left\{\begin{array}{l}\text { All malignant neoplasms } \\
\text { All other causes of death }\end{array}\right.$ & $\begin{array}{ll}1.15 & (51) \\
1.08 & (125)\end{array}$ & $\begin{array}{l}1.27(44) \\
1.09(102)\end{array}$ & $\begin{array}{ll}1.61^{\star} & (36) \\
1.09 & (70)\end{array}$ & $\begin{array}{l}1 \cdot 75^{\star} \\
1.37\end{array}$ & $\begin{array}{l}(20) \\
(42)\end{array}$ \\
\hline$x+\gamma+$ neutron $+\beta$ & $\left\{\begin{array}{l}\text { All malignant neoplasms } \\
\text { All other causes of death }\end{array}\right.$ & $\begin{array}{l}1.05 \quad(75) \\
0.97 \quad(183)\end{array}$ & $\begin{array}{l}1.13(63) \\
0.99(152)\end{array}$ & $\begin{array}{l}1.34 \quad(49) \\
1.00(106)\end{array}$ & $\begin{array}{l}1.65 \star \\
1.27\end{array}$ & $\begin{array}{l}(31) \\
(66)\end{array}$ \\
\hline \multicolumn{7}{|c|}{ Workers with any measured exposure compared with other workers with radiation record } \\
\hline Neutron & $\left\{\begin{array}{l}\text { All malignant neoplasms } \\
\text { All other causes of death }\end{array}\right.$ & $\begin{array}{ll}0.54^{\star} & (13) \\
1 \cdot 18 & (67)\end{array}$ & $\begin{array}{l}0.63(11) \\
1.36(58)\end{array}$ & $\begin{array}{ll}0.84 & (9) \\
1.19 & (34)\end{array}$ & $\begin{array}{l}0.36 \\
1 \cdot 22\end{array}$ & $\begin{array}{r}(2) \\
(18)\end{array}$ \\
\hline$\beta$ (External) & $\left\{\begin{array}{l}\text { All malignant neoplasms } \\
\text { All other causes of death }\end{array}\right.$ & $\begin{array}{ll}1.04 & (230) \\
0.93 & (574)\end{array}$ & $\begin{array}{l}1.09(193) \\
1 \cdot 19(508)\end{array}$ & $\begin{array}{ll}1.20 & (148) \\
1.03 & (374)\end{array}$ & $\begin{array}{l}1.66^{\star \star} \\
1.00\end{array}$ & $\begin{array}{r}(98) \\
(213)\end{array}$ \\
\hline Tritium & $\left\{\begin{array}{l}\text { All malignant neoplasms } \\
\text { All other causes of death }\end{array}\right.$ & $\begin{array}{ll}1.02 & (34) \\
0.97 & (86)\end{array}$ & $\begin{array}{ll}1.06 & (27) \\
1.07 & (74)\end{array}$ & $\begin{array}{ll}1 \cdot 13 & (20) \\
1 \cdot 12 & (54)\end{array}$ & $\begin{array}{l}1.05 \\
0.95\end{array}$ & $\begin{array}{l}(10) \\
(24)\end{array}$ \\
\hline
\end{tabular}

${ }^{\star} \mathrm{p}<0.05 ;{ }^{\star \star} \mathrm{p}<0.01$

TABLE IX-Standardised mortality ratios (observed numbers of deaths in parentheses) and rate ratios for selected causes of death in employees monitored for exposure to specified radionuclides, lagging exposures by two years for leukaemia and 10 years for all other causes of death

\begin{tabular}{|c|c|c|c|c|c|c|c|c|c|c|c|c|}
\hline \multirow[b]{2}{*}{$\begin{array}{l}\text { Cause of death } \\
\text { (ICD code (8th revision)) }\end{array}$} & \multicolumn{2}{|c|}{ Tritium } & \multicolumn{2}{|c|}{ Plutonium } & \multicolumn{2}{|c|}{ Uranium } & \multicolumn{2}{|c|}{ Polonium } & \multicolumn{2}{|c|}{ Actinium } & \multirow{2}{*}{$\begin{array}{l}\text { Standardised } \\
\text { mortality } \\
\text { ratio } \\
\text { for any } \\
\text { radionuclide }\end{array}$} & \multirow{2}{*}{$\begin{array}{l}\text { Standardised } \\
\text { mortality } \\
\text { ratio } \\
\text { for no } \\
\text { radionuclide }\end{array}$} \\
\hline & $\begin{array}{l}\text { Standardised } \\
\text { mortality } \\
\text { ratio }\end{array}$ & $\begin{array}{l}\text { Rate } \\
\text { ratiot }\end{array}$ & $\begin{array}{l}\text { Standardised } \\
\text { mortality } \\
\text { ratio }\end{array}$ & $\begin{array}{l}\text { Rate } \\
\text { ratiof }\end{array}$ & $\begin{array}{l}\text { Standardised } \\
\text { mortality } \\
\text { ratio }\end{array}$ & $\begin{array}{l}\text { Rate } \\
\text { ratiof }\end{array}$ & $\begin{array}{l}\text { Standardised } \\
\text { mortality } \\
\text { ratio }\end{array}$ & $\begin{array}{l}\text { Rate } \\
\text { ratiot }\end{array}$ & $\begin{array}{l}\text { Standardised } \\
\text { mortality } \\
\text { ratio }\end{array}$ & $\begin{array}{l}\text { Rate } \\
\text { ratiof }\end{array}$ & & \\
\hline $\begin{array}{l}\text { All malignant neoplasms (140-209) } \\
\text { Oesophagus (150) } \\
\text { Stomach (151) } \\
\text { Large intestine (153) } \\
\text { Rectum (154) } \\
\text { Pancreas (157) } \\
\text { Bronchus and lung (162) } \\
\text { Prostate (185) }\end{array}$ & $\begin{array}{l}79(20) \\
0(0) \\
41(1) \\
191(3) \\
173(2) \\
0(0) \\
58(6) \\
250(3)\end{array}$ & $\begin{array}{l}1.03 \\
0.00 \\
0.50 \\
2 \cdot 12 \\
2 \cdot 73 \\
0.00 \\
1.02 \\
1.27\end{array}$ & $\begin{array}{l}81(60) \\
177(4) \\
67(5) \\
87(4) \\
148(5) \\
30(1) \\
80(24) \\
168(6)\end{array}$ & $\begin{array}{l}1 \cdot 10 \\
2.09 \\
0.98 \\
0.75 \\
1.86 \\
0.35 \\
1.66 \\
1.06\end{array}$ & $\begin{array}{l}88(37) \\
76(1) \\
50(2) \\
155(4) \\
105(2) \\
54(1) \\
65(11) \\
281(6)^{\star}\end{array}$ & $\begin{array}{l}1.14 \\
0.54 \\
0.65 \\
1.85 \\
1.44 \\
0.35 \\
1.07 \\
1.67\end{array}$ & $\begin{array}{l}104(33) \\
317(3) \\
93(3) \\
206(4) \\
69(1) \\
71(1) \\
85(11) \\
257(4)\end{array}$ & $\begin{array}{l}1.39 \\
4.07 \\
1.47 \\
2.29 \\
0.73 \\
0.35 \\
1.39 \\
1.90\end{array}$ & $\begin{array}{l}117(9) \\
833(2)^{\star} \\
0(0) \\
212(1) \\
0(0) \\
0(0) \\
94(3) \\
242(1)\end{array}$ & $\begin{array}{c}1 \cdot 52 \\
10 \cdot 74^{\star} \\
0 \cdot 00 \\
2 \cdot 34 \\
0.00 \\
0.00 \\
1 \cdot 70 \\
1 \cdot 25\end{array}$ & $\begin{array}{l}79(81)^{\star} \\
129(4) \\
59(6) \\
79(5) \\
129(6) \\
66(3) \\
71(29) \\
164(8)\end{array}$ & $\begin{array}{c}79(194) \star \star \\
89(6) \\
70(18) \\
121(18) \\
82(9) \\
115(12) \\
61(56)^{\star \star} \\
127(12)\end{array}$ \\
\hline $\begin{array}{l}\text { Bladder and other urinary } \\
(188-189 \text { except } 189 \cdot 0) \\
\text { Kidney }(189 \cdot 0) \\
\text { Brain and nervous system }\end{array}$ & $\begin{array}{l}103(1) \\
227(1)\end{array}$ & $\begin{array}{l}2 \cdot 09 \\
1 \cdot 19\end{array}$ & $\begin{array}{r}0(0) \\
240(3)\end{array}$ & $\begin{array}{l}0.00 \\
1 \cdot 23\end{array}$ & $\begin{array}{r}61(1) \\
430(3)\end{array}$ & $\begin{array}{l}1 \cdot 68 \\
2 \cdot 10\end{array}$ & $\begin{array}{c}0(0) \\
576(3)^{\star}\end{array}$ & $\begin{array}{l}0 \cdot 00 \\
3 \cdot 77\end{array}$ & $\begin{array}{l}0(0) \\
0(0)\end{array}$ & $\begin{array}{l}0.00 \\
0.00\end{array}$ & $\begin{array}{r}50(2) \\
291(5)\end{array}$ & $\begin{array}{r}52(5) \\
146(6)\end{array}$ \\
\hline $\begin{array}{l}(191-192,225,238) \ddagger \\
\text { Ill defined and secondary (195-199) } \\
\text { All lymphatic and haemopoietic }\end{array}$ & $\begin{array}{l}128(1) \\
170(2)\end{array}$ & $\begin{array}{l}\infty \star \star \\
1 \cdot 34\end{array}$ & $\begin{array}{r}46(1) \\
110(4)\end{array}$ & $\begin{array}{l}5 \cdot 25 \\
0 \cdot 73\end{array}$ & $\begin{array}{r}85(1) \\
200(4)\end{array}$ & $\begin{array}{r}93.73 \\
1.61\end{array}$ & $\begin{array}{r}0(0) \\
63(1)\end{array}$ & $\begin{array}{l}0.00 \\
0.45\end{array}$ & $\begin{array}{r}0(0) \\
280(1)\end{array}$ & $\begin{array}{l}0.00 \\
1.93\end{array}$ & $\begin{array}{r}33(1) \\
159(8)\end{array}$ & $\begin{array}{l}34(3) \\
91(15)\end{array}$ \\
\hline $\begin{array}{l}\text { (200-209) } \\
\text { Non-Hodgkin's lymphoma }\end{array}$ & $65(1)$ & $1 \cdot 31$ & $45(2)$ & 0.66 & $41(1)$ & 0.52 & $109(2)$ & $2 \cdot 11$ & $230(1)$ & $3 \cdot 50$ & $33(2)$ & $54(9)$ \\
\hline $\begin{array}{l}\text { Multiple myeloma (203) } \\
\text { Leukaemia }(204-208)\end{array}$ & $\begin{array}{r}227(1) \\
0(0) \\
0(0)\end{array}$ & $\begin{array}{l}8 \cdot 34 \\
0 \cdot 00 \\
0 \cdot 00\end{array}$ & $\begin{array}{r}81(1) \\
125(1) \\
0(0)\end{array}$ & $\begin{array}{l}1.43 \\
2.66 \\
0.00\end{array}$ & $\begin{array}{r}144(1) \\
0(0) \\
0(0)\end{array}$ & $\begin{array}{l}2 \cdot 25 \\
0 \cdot 00 \\
0 \cdot 00\end{array}$ & $\begin{array}{r}198(1) \\
298(1) \\
0(0)\end{array}$ & $\begin{array}{l}4 \cdot 76 \\
6 \cdot 34 \\
0 \cdot 00\end{array}$ & $\begin{array}{r}813(1) \\
0(0) \\
0(0)\end{array}$ & $\begin{array}{r}19 \cdot 68 \\
0.00 \\
0.00\end{array}$ & $\begin{array}{r}58(1) \\
91(1) \\
0(0)\end{array}$ & $\begin{array}{l}45(2) \\
41(1) \\
60(4)\end{array}$ \\
\hline \multirow{3}{*}{$\begin{array}{l}\text { All causes except malignant } \\
\text { neoplasms }(0-139,210-999) \\
\text { All diseases of circulatory } \\
\text { system ( } 390-458) \\
\text { All diseases of respiratory system } \\
(460-519)\end{array}$} & $92(64)$ & $1 \cdot 26$ & $82(170)^{\star \star}$ & $1 \cdot 11$ & $87(100)$ & $1 \cdot 17$ & $85(75)$ & $1 \cdot 15$ & $90(19)$ & $1 \cdot 13$ & $83(238)^{\star \star}$ & $66(459)^{\star \star}$ \\
\hline & $102(49)$ & $1 \cdot 27$ & $91(129)$ & $1 \cdot 11$ & $91(72)$ & $1 \cdot 11$ & $89(54)$ & 1.08 & $102(15)$ & $1 \cdot 18$ & $94(184)$ & $74(333)^{\star \star}$ \\
\hline & $64(7)$ & 1.06 & $68(23)$ & 1.05 & $74(14)$ & $1 \cdot 03$ & $80(12)$ & $1 \cdot 36$ & $57(2)$ & 0.77 & $56(62)^{\star \star}$ & $62(29)^{\star \star}$ \\
\hline All causes $(0-999)$ & $89(84)$ & $1 \cdot 19$ & $82(230)^{\star \star}$ & $1 \cdot 10$ & $88(137)$ & $1 \cdot 16$ & $90(108)$ & $1 \cdot 21$ & $98(28)$ & $1 \cdot 23$ & $82(319)^{\star \star}$ & $69(653)^{\star \star}$ \\
\hline $\begin{array}{l}\text { Person years at risk ( } 10 \text { year lag) } \\
\text { No of workers ever monitored }\end{array}$ & $\begin{array}{l}6987 \\
1562\end{array}$ & & $\begin{array}{r}1980 \\
374\end{array}$ & & $\begin{array}{rl}10 & 03 \\
3 & 04\end{array}$ & & $\begin{array}{r}7589 \\
638\end{array}$ & & $\begin{array}{r}1574 \\
281\end{array}$ & & $\begin{array}{r}28356 \\
4742\end{array}$ & $\begin{array}{r}117359 \\
4647\end{array}$ \\
\hline
\end{tabular}

${ }^{\star} \mathrm{p}<0.05 ; * \star \mathrm{p}<0.01$

tRelative to other workers with radiation record and adjusted for age, sex, calendar period, and social class.

łIncludes benign and unspecified neoplasms of nervous system.

Rate ratios are adjusted for age, sex, calendar period, and social class. When no lag was assumed rate ratios for all malignant neoplasms were close to 1.0 regardless of type of radiation considered, but the rate ratios increased the longer the lag and were significant with lags of 10 and 15 years. For all other causes of death no rate ratios were significant and their values for lags of up to 10 years were generally close to $1 \cdot 0$; with a lag of 15 years rate ratios were greater than unity and examination of broad groupings of causes suggested that this was due largely to mortality from diseases of the respiratory system. The rate ratio for mortality from respiratory disease was $2 \cdot 7$ (95\% confidence interval 1.3 to 5.4 ) for whole body exposure allowing for a 15 year lag, similar results being obtained for surface exposure and $x$ plus $\gamma$ ray exposure. There was considerable overlap among the different measures of radiation exposure, workers accumulating high exposures of one type also tending to accumulate high exposures of others. Thus the findings for the different types of radiation exposure and the associated significance tests are not independent.

Analyses were performed to assess whether for workers with radiation records any specific type of radiation exposure might be associated with mortality. Exposure to $x$ rays and $\gamma$ rays could not be separated, but the contributions from neutrons, $\beta$ rays (from external sources), and tritium (from internal sources) could. Comparison of mortality of workers with any measured exposure to neutrons, $\beta$ rays (external), or tritium in relation to other workers with a radiation record is shown in the lower part of table VIII. Mortality from cancer in those with a measured neutron exposure was significantly lower than among other workers with a radiation record, but the deficit became smaller and non-significant after a lag of five or 10 years was assumed. For those with measured exposure to $\beta$ radiation from external sources the rate ratios for cancer but not other causes of death increased as longer lags were assumed, the rate ratio after 15 years being significantly raised. For those with 


\begin{tabular}{|c|c|c|c|c|c|c|c|c|}
\hline \multirow[b]{3}{*}{$\begin{array}{c}\text { Cause of death } \\
\text { (ICD code }(8 \text { th revision }))\end{array}$} & \multicolumn{4}{|c|}{$\begin{array}{l}\text { Employees not monitored for radionuclide exposure and with } \\
\text { cumulative whole body exposure of: }\end{array}$} & \multicolumn{4}{|c|}{$\begin{array}{l}\text { Employees monitored for radionuclide exposure and with } \\
\text { cumulative whole body exposure of: }\end{array}$} \\
\hline & \multicolumn{2}{|c|}{$<10 \mathrm{mSv}$} & \multicolumn{2}{|c|}{$\geqslant 10 \mathrm{mSv}$} & \multicolumn{2}{|c|}{$<10 \mathrm{mSv}$} & \multicolumn{2}{|c|}{$\geqslant 10 \mathrm{mSv}$} \\
\hline & $\begin{array}{l}\text { Standardised } \\
\text { mortality ratio }\end{array}$ & Rate ratiof & $\begin{array}{l}\text { Standardised } \\
\text { mortality ratio }\end{array}$ & Rate ratio & $\begin{array}{l}\text { Standardised } \\
\text { mortality ratio }\end{array}$ & Rate ratio & $\begin{array}{l}\text { Standardised } \\
\text { mortality ratio }\end{array}$ & Rate ratio \\
\hline All malignant neoplasms $(140-209)$ & $78(186)^{\star \star}$ & 1.0 & $79(8)$ & $1 \cdot 2$ & $68(53)^{\star \star}$ & 0.9 & $115(28)$ & $1 \cdot 6^{\star}$ \\
\hline Oesophagus $(150)$ & $78(5)$ & 1.0 & $314(1)$ & $11 \cdot 2$ & $86(2)$ & 1.0 & $259(2)$ & $3 \cdot 3$ \\
\hline Stomach $(151)$ & $69(17)$ & $1 \cdot 0$ & $104(1)$ & 1.5 & $64(5)$ & 0.9 & $42(1)$ & 0.6 \\
\hline Large intestine (153) & $112(16)$ & $1 \cdot 0$ & $320(2)$ & $3 \cdot 1$ & $83(4)$ & 0.8 & $66(1)$ & 0.6 \\
\hline Rectum (154) & $86(9)$ & $1 \cdot 0$ & $0(0)$ & $0 \cdot 0$ & $85(3)$ & 0.9 & $270(3)$ & $3 \cdot 7$ \\
\hline Pancreas (157) & $110(11)$ & $1 \cdot 0$ & $221(1)$ & $2 \cdot 6$ & $29(1)$ & 0.4 & $182(2)$ & $2 \cdot 7$ \\
\hline Bronchus and lung (162) & $63(55)^{\star \star}$ & 1.0 & $25(1)$ & 0.8 & $58(18)^{\star}$ & $1 \cdot 2$ & $111(11)$ & $2 \cdot 1$ \\
\hline Prostate $(185)$ & $133(12)$ & $1 \cdot 0$ & $0(0)$ & 0.0 & $134(5)$ & 0.8 & $258(3)$ & $1 \cdot 3$ \\
\hline \multicolumn{9}{|l|}{ Bladder and other urinary (188-189 except } \\
\hline $189 \cdot 0)$ & $54(5)$ & $1 \cdot 0$ & $0(0)$ & 0.0 & $32(1)$ & 0.5 & $106(1)$ & $2 \cdot 5$ \\
\hline Kidney $(189 \cdot 0)$ & $127(5)$ & 1.0 & $552(1)$ & $2 \cdot 8$ & $309(4)$ & $2 \cdot 2$ & $236(1)$ & $1 \cdot 2$ \\
\hline Brain and nervous system $(191-192,225,238) \ddagger$ & $35(3)$ & 1.0 & $0(0)$ & 0.0 & $43(1)$ & 0.8 & $0(0)$ & $0 \cdot 0$ \\
\hline Ill defined and secondary (195-199) & $88(14)$ & 1.0 & $199(1)$ & $2 \cdot 6$ & $154(6)$ & $1 \cdot 2$ & $174(2)$ & 1.8 \\
\hline All lymphatic and haemopoietic $(200-209)$ & $56(9)$ & 1.0 & $0(0)$ & 0.0 & $21(1)$ & $0 . \overline{2}$ & $69(1)$ & 0.8 \\
\hline Non-Hodgkin's lymphoma $(200,202)$ & $47(2)$ & $1 \cdot 0$ & $0(0)$ & 0.0 & $0(0)$ & 0.0 & $241(1)$ & $3 \cdot 6$ \\
\hline Multiple myeloma (203) & $43(1)$ & $1 \cdot 0$ & $0(0)$ & 0.0 & $122(1)$ & $2 \cdot 1$ & $0(0)$ & 0.0 \\
\hline Leukaemia (204-208) & $62(4)$ & 1.0 & $0(0)$ & $0 \cdot 0$ & $0(0)$ & 0.0 & $0(0)$ & 0.0 \\
\hline \multicolumn{9}{|l|}{ All causes except malignant neoplasms } \\
\hline$(0-139,210-999)$ & $66(446)^{\star \star}$ & 1.0 & $47(13)^{\star \star}$ & 0.8 & $81(177)^{\star \star}$ & $1 \cdot 1$ & $91(61)$ & $1 \cdot 3$ \\
\hline All diseases of circulatory system (390-458) & $75(324)^{\star \star}$ & $1 \cdot 0$ & $48(9)$ & $0 \cdot 7$ & $95(141)$ & $1 \cdot 2$ & $93(43)$ & $1 \cdot 2$ \\
\hline All diseases of respiratory system $(460-519)$ & $56(60)^{\star \star}$ & $1 \cdot 0$ & $48(2)$ & $1 \cdot 0$ & $47(17)$ & 0.7 & $113(12)$ & $2 \cdot 0$ \\
\hline All causes $(0-999)$ & $70(632)^{\star \star}$ & 1.0 & $56(21)^{\star \star}$ & 0.9 & $78(230)^{\star \star}$ & $1 \cdot 1$ & $98(89)$ & $1 \cdot 4^{\star}$ \\
\hline
\end{tabular}

${ }^{\star} \mathrm{p}<0.05 ;{ }^{\star \star} \mathrm{p}<0 \cdot 01$.

tReference group for estimation of rate ratio; all rate ratios adjusted for age, sex, calendar period, and social class.

$\ddagger$ Includes benign and unspecified neoplasms of nervous system.

assessed tritium exposures there were no notable findings.

\section{MORTALITY AND MONITORING FOR INTERNAL EXPOSURE TO RADIONUCLIDES}

Mortality in workers monitored for possible internal exposure to specific radionuclides was examined by calculating standardised mortality ratios for comparison with national rates and rate ratios for comparison with other workers who had a radiation record but were not monitored for that particular radionuclide. When no lag was assumed mortality from all malignant neoplasms was similar in workers monitored for exposure to radionuclides and others with a radiation record who were not monitored for radionuclide exposure (standardised mortality ratios 79 in both groups). There were, however, nonsignificant excesses of lung, prostatic, and renal cancers in workers monitored for radionuclide exposure. With a 10 year lag the mortality from all malignant neoplasms was still 79 in both groups. Standardised mortality ratios for prostatic and renal cancers remained raised and were generally greater than 200 for each specific type of radionuclide considered (table IX), the excess being significant for prostatic cancer in workers monitored for uranium exposure $(p=0.04)$ and for cancer of the kidney in workers monitored for polonium exposure $(p=0 \cdot 03)$. Many workers were monitored for internal contamination by more than one radionuclide and the same eight men with prostatic cancer and five men and one woman with renal cancer were responsible for most of the raised standardised mortality ratios and rate ratios.

Mortality from bronchial and lung cancer was significantly lower than the national average in radiation workers who were not monitored for radionuclide contamination (standardised mortality ratio $61 ; p<0.01)$. Though the mortality from lung cancer in workers monitored for exposure to plutonium was also below the national average, it was raised in comparison with other radiation workers (rate ratio $1.66 ; p=0 \cdot 06$ ). Rate ratios for lung cancer were also raised in workers monitored for polonium and actinium exposure but not in workers monitored for exposure to tritium and uranium, though the excesses were not significant and all the workers contributing to the raised rate ratios were also monitored for exposure to plutonium. Mortality from oesophageal cancer in workers monitored for exposure to actinium was significantly raised in comparison with both national rates and other radiation workers (standardised mortality ratio $833, p=0.05$; rate ratio $10 \cdot 74, p=0.01$ ), this finding being based on only two deaths. Among workers monitored for exposure to radionuclides only one death was attributed, respectively, to a nervous system tumour, multiple myeloma, and non-Hodgkin's lymphoma and so the corresponding standardised mortality ratios and rate ratios were unstable. No death attributed to leukaemia was reported in any worker monitored for exposure to any radionuclide.

Workers with relatively high exposures to external radiation are also likely to be monitored for internal contamination. Of the 1574 workers with external whole body exposures of $10 \mathrm{mSv}$ or more, $1200(76 \%)$ were also monitored for possible contamination by one or more radionuclides, whereas only $3508(45 \%)$ of those with external exposures of less than $10 \mathrm{mSv}$ were similarly monitored. Table $\mathrm{X}$ shows the standardised mortality ratios and rate ratios in radiation workers cross classified by both internal and external exposures, allowing a 10 year lag. The numbers of deaths in each category were small and no standardised mortality ratio was significantly greater than 100 , but the rate ratios were generally in excess of 1.0 in the workers who both were monitored for internal contamination and had cumulative external exposures of $10 \mathrm{mSv}$ or more. In that group the rate ratios for all causes and all malignant neoplasms were significantly greater than $1 \cdot 0$; the corresponding rate ratios for lung cancer and all diseases of the respiratory system were of borderline significance (rate ratio $2.12, p=0.05$; rate ratio 1.97 , $\mathrm{p}=0 \cdot 06$, respectively).

Mortality from all cancers, bronchial and lung cancer, prostatic cancer, and non-malignant diseases of the respiratory system increased after a 10 year lag with increasing cumulative exposure to external whole body irradiation (table VII). When workers were further classified according to monitoring for internal sources of radiation the trends of increasing mortality with increasing external exposure were largely confined to the workers monitored for exposure to radionuclides 
(table XI). In these workers mortality from lung cancer rose steadily with increasing exposure to external radiation $(\mathrm{p}<0.001)$, no similar trend being evident in workers who were not monitored for radionuclides $(p=0.98)$. Examination of the data for each specific radionuclide showed that the trend for lung cancer was further confined to workers monitored for exposure to plutonium: of the 12 deaths in those who accumulated more than $10 \mathrm{mSv}$ of external exposure, 10 were monitored for plutonium, five of whom were monitored for uranium, four for polonium, and two for actinium. An eleventh man was monitored for uranium alone, and only one was not monitored for any specific radionuclide. The trend of increasing mortality from prostatic cancer with increasing exposure to external radiation was also largely confined to workers monitored for exposure to radionuclides, though the numbers were small. Table XI presents the data for tritium, as prostatic cancer has been related to this radionuclide in other workforces, ${ }^{7}$ and for uranium, as the excess in this population was significant (table IX). The trend with increasing external exposure was significant in men monitored for tritium $(p<0.001$ based on approximate $\chi^{2}$ test for trend; $p=0.02$ based on 10000 simulations) and uranium $(p<0.05)$ but not in other radiation workers who were not monitored for radionuclides $(p=0 \cdot 48)$. The findings for prostatic cancer were broadly similar for each specific radionuclide, the same workers with multiple exposures featuring repeatedly in the results.

Increases in relative risk per $10 \mathrm{mSv}$ for all malignant neoplasms were estimated for the data presented in tables VI and VII. When a multiplicative relative risk model was fitted to the data assuming no lag the relative risk was estimated to increase by $1.3 \%$ ( $95 \%$ confidence interval $-4 \cdot 1 \%$ to $7 \cdot 1 \%$ ) for each $10 \mathrm{mSv}$ of exposure; fitting an additive model resulted in an estimated relative excess risk per $10 \mathrm{mSv}$ of $0.6 \%$ (95\% confidence interval $-5 \cdot 3 \%$ to $6 \cdot 6 \%)$. With a 10 year lag the corresponding estimates were $7 \cdot 6 \%(95 \%$ confidence interval $0 \cdot 4 \%$ to $15 \cdot 3 \%)$ and $8 \cdot 1 \%$ (95\% confidence interval $-4 \cdot 0 \%$ to $20 \cdot 2 \%$ ), respectively.

\section{Discussion}

This is the third large investigation in the United Kingdom of the mortality of employees in the nuclear industry, the study population of 22552 being smaller than that of the United Kingdom Atomic Energy Authority ${ }^{7}$ but larger than that at Sellafield. ${ }^{10}$ The study design and methods of analysis were broadly similar in all three studies and so the findings of this study will be mainly compared with and interpreted in the context of the other two. Though there were many similarities among the workforces, differences existed in the level and type of exposures and the work done. The average cumulative whole body exposure in workers with a radiation record was $7.8 \mathrm{mSv}$ in employees of the Atomic Weapons Establishment, compared with $32.4 \mathrm{mSv}$ in United Kingdom Atomic Energy Authority employees and $124.0 \mathrm{mSv}$ at Sellafield. As the recorded exposures at the Atomic Weapons Establishment were lower than in the other two workforces, the power of this study to detect any effects of external radiation was also lower. Workers at the Atomic Weapons Establishment monitored for exposure to radiation, however, were more likely than those at the United Kingdom Atomic Energy Authority to be monitored for internal exposure to radionuclides such as plutonium $(40 \%$ and $14 \%$, respectively) or tritium $(17 \%$ and $7 \%)$. The range of radionuclides to which they were exposed also differed: $7 \%$ of workers at the Atomic Weapons Establishment who were monitored for exposure to radiation were monitored for exposure to polonium and $3 \%$ for exposure to actinium, monitoring for such exposures being rare in the United Kingdom Atomic

TABLE XI-Standardised mortality ratios (observed/expected t numbers of deaths) and rate ratios for selected causes of death stratified by level of cumulative whole body exposure and monitoring for exposure to radionuclides, lagging exposures by 10 years

\begin{tabular}{|c|c|c|c|c|c|c|c|}
\hline \multirow{2}{*}{\multicolumn{2}{|c|}{$\begin{array}{c}\text { Cause of death } \\
\text { (ICD code }(8 \text { th revision }))\end{array}$}} & \multicolumn{5}{|c|}{ Cumulative whole body exposure (mSv) } & \multirow{2}{*}{$\begin{array}{c}\chi^{2} \text { Test } \\
\text { for trend on } 1 \mathrm{df} \\
\text { (direction of trend) }\end{array}$} \\
\hline & & $<10$ & $10-$ & $20-$ & $50-$ & $\geqslant 100$ & \\
\hline $\begin{array}{l}\text { All malignant neoplasms }(140-209) \text { : } \\
\text { Monitored for any radionuclide }\end{array}$ & $\left\{\begin{array}{l}\text { Standardised mortality ratio } \\
\text { Rate ratio }\end{array}\right.$ & $\begin{array}{c}68 \star \star(53 / 77 \cdot 70) \\
0 \cdot 9\end{array}$ & $\begin{array}{c}132(14 / 10 \cdot 62) \\
1 \cdot 8\end{array}$ & $\begin{array}{c}87(8 / 9 \cdot 16) \\
1 \cdot 1\end{array}$ & $\begin{array}{c}99(3 / 3.04) \\
1.4\end{array}$ & $\begin{array}{c}196(3 / 1 \cdot 53) \\
2 \cdot 5\end{array}$ & $6.02(+)^{\star}$ \\
\hline Not monitored for any radionuclide & $\left\{\begin{array}{l}\text { Standardised mortality ratio } \\
\text { Rate ratio }\end{array}\right.$ & $\begin{array}{c}78^{\star \star}(186 / 236 \cdot 96) \\
1 \cdot 0 \ddagger\end{array}$ & $\begin{array}{c}75(4 / 5 \cdot 32) \\
1 \cdot 0\end{array}$ & $\begin{array}{c}85(3 / 3.51) \\
1.5\end{array}$ & $\begin{array}{c}117(1 / 0 \cdot 85) \\
2 \cdot 3\end{array}$ & $\begin{array}{l}0(0 / 0 \cdot 42) \\
0.0\end{array}$ & $0 \cdot 17(+)$ \\
\hline $\begin{array}{l}\text { Bronchial and lung cancer (162): } \\
\text { Monitored for any radionuclide }\end{array}$ & $\left\{\begin{array}{l}\text { Standardised mortality ratio } \\
\text { Rate ratio }\end{array}\right.$ & $\begin{array}{c}58 \star(18 / 31 \cdot 17) \\
1 \cdot 2\end{array}$ & $\begin{array}{c}46(2 / 4 \cdot 35) \\
0.9\end{array}$ & $\begin{array}{c}134(5 / 3 \cdot 74) \\
2 \cdot 6\end{array}$ & $\begin{array}{c}166(2 / 1 \cdot 20) \\
3 \cdot 5\end{array}$ & $\begin{array}{c}313(2 / 0 \cdot 64) \\
5 \cdot 6\end{array}$ & $5.52(+)^{\star}$ \\
\hline Not monitored for any radionuclide & $\left\{\begin{array}{l}\text { Standardised mortality ratio } \\
\text { Rate ratio }\end{array}\right.$ & $\begin{array}{c}63 \star \star(55 / 87 \cdot 31) \\
1 \cdot 0 \ddagger\end{array}$ & $\begin{array}{c}0(0 / 2 \cdot 12) \\
0 \cdot 0\end{array}$ & $\begin{array}{c}73(1 / 1 \cdot 37) \\
4 \cdot 2\end{array}$ & $\begin{array}{l}0(0 / 0 \cdot 34) \\
0.0\end{array}$ & $\begin{array}{l}0(0 / 0 \cdot 18) \\
0 \cdot 0\end{array}$ & $0 \quad(-)$ \\
\hline Monitored for plutonium & $\left\{\begin{array}{l}\text { Standardised mortality ratio } \\
\text { Rate ratio }\end{array}\right.$ & $\begin{array}{c}61(14 / 23 \cdot 03) \\
1 \cdot 3\end{array}$ & $\begin{array}{c}68(2 / 2 \cdot 95) \\
1 \cdot 3\end{array}$ & $\begin{array}{c}157(4 / 2 \cdot 54) \\
3 \cdot 1\end{array}$ & $\begin{array}{c}184(2 / 1 \cdot 09) \\
4 \cdot 0\end{array}$ & $\begin{array}{c}382(2 / 0 \cdot 52) \\
6 \cdot 7^{\star}\end{array}$ & $13.95(+)^{\star \star}$ \\
\hline Not monitored for plutonium & $\left\{\begin{array}{l}\text { Standardised mortality ratio } \\
\text { Rate ratio }\end{array}\right.$ & $\begin{array}{c}62^{\star \star}(59 / 95 \cdot 44) \\
1 \cdot 0 \ddagger\end{array}$ & $\begin{array}{c}0(0 / 3.52) \\
0.0\end{array}$ & $\begin{array}{c}78(2 / 2 \cdot 56) \\
2 \cdot 6\end{array}$ & $\begin{array}{c}0(0 / 0 \cdot 46) \\
0 \cdot 0\end{array}$ & $\begin{array}{l}0(0 / 0 \cdot 29) \\
0 \cdot 0\end{array}$ & $0 \quad(-)$ \\
\hline $\begin{array}{l}\text { Prostatic cancer ( } 185 \text { ): } \\
\text { Monitored for tritium }\end{array}$ & $\left\{\begin{array}{l}\text { Standardised mortality ratio } \\
\text { Rate ratio }\end{array}\right.$ & $\begin{array}{c}120(1 / 0 \cdot 83) \\
0.5\end{array}$ & $\begin{array}{c}551(1 / 0 \cdot 18) \\
3 \cdot 2\end{array}$ & $\begin{array}{l}0(0 / 0 \cdot 10) \\
0 \cdot 0\end{array}$ & $\begin{array}{l}0(0 / 0 \cdot 07) \\
0.0\end{array}$ & $\begin{array}{c}4928^{\star}(1 / 0 \cdot 02) \\
17 \cdot 4^{\star \star}\end{array}$ & $14.96(+)^{\star \star}$ \\
\hline Not monitored for tritium & $\left\{\begin{array}{l}\text { Standardised mortality ratio } \\
\text { Rate ratio }\end{array}\right.$ & $\begin{array}{c}134(16 / 11 \cdot 92) \\
1 \cdot 0 \ddagger\end{array}$ & $\begin{array}{c}0(0 / 0 \cdot 56) \\
0.0\end{array}$ & $\begin{array}{c}204(1 / 0 \cdot 49) \\
1 \cdot 1\end{array}$ & $\begin{array}{l}0(0 / 0 \cdot 13) \\
0 \cdot 0\end{array}$ & $\begin{array}{l}0(0 / 0.05) \\
0.0\end{array}$ & $0.33(-)$ \\
\hline Monitored for uranium & $\left\{\begin{array}{l}\text { Standardised mortality ratio } \\
\text { Rate ratio }\end{array}\right.$ & $\begin{array}{c}216(3 / 1 \cdot 39) \\
1 \cdot 1\end{array}$ & $\begin{array}{c}333(1 / 0 \cdot 30) \\
2 \cdot 0\end{array}$ & $\begin{array}{c}323(1 / 0 \cdot 31) \\
1 \cdot 4\end{array}$ & $\begin{array}{c}0(0 / 0 \cdot 11) \\
0 \cdot 0\end{array}$ & $\begin{array}{c}3393(1 / 0 \cdot 03) \\
14 \cdot 1^{\star}\end{array}$ & $6.58(+)^{\star}$ \\
\hline Not monitored for uranium & $\left\{\begin{array}{l}\text { Standardised mortality ratio } \\
\text { Rate ratio }\end{array}\right.$ & $\begin{array}{c}123(14 / 11 \cdot 37) \\
1 \cdot 0 \ddagger\end{array}$ & $\begin{array}{c}0(0 / 0 \cdot 45) \\
0.0\end{array}$ & $\begin{array}{c}0(0 / 0 \cdot 28) \\
0 \cdot 0\end{array}$ & $\begin{array}{c}0(0 / 0.09) \\
0.0\end{array}$ & $\begin{array}{l}0(0 / 0.04) \\
0.0\end{array}$ & $0.77(-)$ \\
\hline $\begin{array}{l}\text { All diseases of respiratory system } \\
(460-519) \text { : }\end{array}$ & & & & & & & \multirow[b]{2}{*}{$5 \cdot 52(+)^{\star}$} \\
\hline Monitored for any radionuclide & $\left\{\begin{array}{l}\text { Standardised mortality ratio } \\
\text { Rate ratio }\end{array}\right.$ & $\begin{array}{c}47^{\star \star}(17 / 36 \cdot 42) \\
0 \cdot 7\end{array}$ & $\begin{array}{c}107(5 / 4 \cdot 67) \\
2 \cdot 2\end{array}$ & $\begin{array}{c}102(4 / 3.91) \\
1.8\end{array}$ & $\begin{array}{c}127(2 / 1 \cdot 57) \\
2 \cdot 3\end{array}$ & $\begin{array}{c}200(1 / 0 \cdot 50) \\
7 \cdot 3\end{array}$ & \\
\hline Not monitored for any radionuclide & $\left\{\begin{array}{l}\text { Standardised mortality ratio } \\
\text { Rate ratio }\end{array}\right.$ & $\begin{array}{c}56^{\star \star}(60 / 107 \cdot 52) \\
1 \cdot 0 \ddagger\end{array}$ & $\begin{array}{c}0(0 / 2 \cdot 27) \\
0 \cdot 0\end{array}$ & $\begin{array}{c}67(1 / 1.49) \\
1.5\end{array}$ & $\begin{array}{c}374(1 / 0 \cdot 27) \\
20 \cdot 7^{\star}\end{array}$ & $\begin{array}{l}0(0 / 0 \cdot 14) \\
0.0\end{array}$ & $0.90(+)$ \\
\hline Monitored for plutonium & $\left\{\begin{array}{l}\text { Standardised mortality ratio } \\
\text { Rate ratio }\end{array}\right.$ & $\begin{array}{c}53^{\star}(14 / 26 \cdot 60) \\
0.8\end{array}$ & $\begin{array}{c}140(4 / 2 \cdot 86) \\
3 \cdot 0\end{array}$ & $\begin{array}{c}77(2 / 2 \cdot 59) \\
1.6\end{array}$ & $\begin{array}{c}135(2 / 1 \cdot 48) \\
2 \cdot 5\end{array}$ & $\begin{array}{c}234(1 / 0 \cdot 43) \\
7 \cdot 5\end{array}$ & $4 \cdot 40(+)^{\star}$ \\
\hline Not monitored for plutonium & $\left\{\begin{array}{l}\text { Standardised mortality ratio } \\
\text { Rate ratio }\end{array}\right.$ & $\begin{array}{c}54^{\star \star}(63 / 117 \cdot 34) \\
1 \cdot 0 \ddagger\end{array}$ & $\begin{array}{c}24(1 / 4 \cdot 08) \\
0 \cdot 5\end{array}$ & $\begin{array}{c}107(3 / 2 \cdot 81) \\
1.9\end{array}$ & $\begin{array}{c}283(1 / 0 \cdot 35) \\
13.9\end{array}$ & $\begin{array}{l}0(0 / 0 \cdot 21) \\
0 \cdot 0\end{array}$ & $1.51(+)$ \\
\hline
\end{tabular}

${ }^{\star} \mathrm{p}<0.05 ;{ }^{\star} \mathrm{p}<0.01$

tExpected deaths calculated by using age, sex, and calendar period specific rates for England and Wales.

tReference group: all rate ratios adjusted for age, sex, calendar period, and social class. 
Energy Authority workforce. Comparable data were not available for Sellafield workers.

The protocol for the Atomic Weapons Establishment study was almost identical with that used for the United Kingdom Atomic Energy Authority study, and the day to day work was performed by the same staff under the guidance of members of the Epidemiological Monitoring Unit. Checks on completeness of the data, especially for the critical deaths from cancer, were carried out by using, as far as possible, sources of information independent of the Atomic Weapons Establishment. Statistics for manpower strength of the United Kingdom Atomic Energy Authority's weapons group, compiled for administrative purposes during 1949-73, agreed closely with our figures after 1950 , indicating that the study population was virtually complete between 1951 and 1973. According to the statistics fewer than 700 people were employed in 1950, and our data suggest that about 200 of them are not included here-that is, less than $1 \%$ of the total workforce enumerated for 1951-82. Examination of deaths from cancer registered in the Oxford Cancer Registry between 1957 and 1983 where the Atomic Weapons Establishment was mentioned as the employer and of haemopoietic cancers treated at the Royal Berkshire Hospital (the largest district general hospital near Aldermaston) identified $6 \%$ of all deaths from cancer in the workforce and did not disclose any Atomic Weapons Establishment employee who had died of cancer who was not already included in the study. Comparison of the computerised radiation records with a sample of the original health physics records indicated that the data had been transcribed completely and accurately. A special search of Atomic Weapons Establishment medical records of the 20 subjects whose death was attributed to leukaemia confirmed that all had been correctly classified with respect to radiation exposure at Atomic Weapons Establishment sites (Atomic Weapons Establishment, personal communication). Though we cannot exclude the possibility that some people may have been missing from the study population after 1950 , or that some of the radiation records may have been missing, there was no evidence from our independent checks that this was a serious problem.

Overall the mortality of the Atomic Weapons Establishment workforce was lower than that in the general population. This finding is common to all workforces in the nuclear industry and is due at least in part to the recruitment of healthy people into the workforce and to the relatively high proportion of workers from social classes I and II, who have lower mortality than the national average. ${ }^{2324}$ Furthermore, Aldermaston and the other Ministry of Defence establishments are situated in south east England, where mortality is below the national average. Though it would have been preferable to base all standardised mortality ratios on rates specific for region and social class, these data were not available for all calendar years, or for mortality from specific cancers. Moreover, the rates would still not be typical of the mortality of a working population, as national rates include the chronically sick and unemployed, who have higher death rates than people in employment.

As no suitable alternatives exist, data for all England and Wales were used for calculating standardised mortality ratios. They provide a stable basis for comparison but describe the level of mortality in the workforce only in a general way in relation to a well defined average. They are of limited value when considering whether radiation exposure might have affected mortality. More relevant is the mortality of workers exposed to radiation compared with the remaining workforce and their mortality in relation to the level of exposure. Here, too, however, the possibility of selection on the basis of health needs to be considered, as employees with chronic illnesses may be excluded or withdrawn from work entailing exposure to radiation. ${ }^{1024}$ As the effects of selection on the basis of health wear off over time and cancers induced by radiation (except leukaemia) do not appear until many years after exposure, findings which are evident after a defined latent period merit particular attention.

Mortality from prostatic cancer was found to be associated with certain radiation exposures. Though the standardised mortality ratio in the entire workforce was 99 , it was 139 in workers with a radiation record compared with 79 in other workers. The ratio of mortality in workers with a radiation record compared with other workers was 1.90 with no lag and 2.23 with a 10 year lag, this second ratio being significantly greater than $1.0(p=0.03$; table $V)$. Among workers monitored for internal exposure to specific radionuclides mortality from prostatic cancer was generally twice the national average for each type of radionuclide, the excess in those monitored for uranium being significant $(p=0.04$; table IX). Moreover, mortality increased with increasing exposure to external radiation, this trend being confined to men who were also monitored for exposure to radionuclides (table XI). These findings were not independent, and eight men dying of prostatic cancer with multiple radionuclide monitoring tended to account for all the significant results. Mortality attributed to hyperplasia of the prostate, though rare, appeared to be more common in radiation workers than other employees (table V).

Taken in conjunction with the findings in other industrial settings, these results suggest that there may be a specific hazard for prostatic cancer within the nuclear industry. A significant excess mortality from prostatic cancer has also been described in workers monitored for exposure to radionuclides in the United Kingdom Atomic Energy Authority workforce, especially in men with comparatively high cumulative exposure to external radiation; multiple radionuclide monitoring was also frequent there, the same nine men accounting for all the significant findings. ' Though two radiation workers who died of prostatic cancer were employed by both the Atomic Weapons Establishment and the United Kingdom Atomic Energy Authority, their exclusion from one or other study would not have altered the findings. At Sellafield there was a non-significant excess mortality from prostatic cancer in radiation workers (standardised mortality ratio $120 ; 19$ deaths observed) but not in other workers (standardised mortality ratio 64; four deaths observed), the corresponding rate ratio being 1.9 ; no data on radionuclide exposure were available at that time and mortality was inversely related to increasing cumulative external exposure. ${ }^{10}$

In workforces in the United States excess mortality from prostatic cancer has been reported in employees of the Oak Ridge National Laboratory (standardised mortality ratio $118 ; 14$ deaths observed $)^{8}$; in craftsmen and operators at Hanford (rate ratio $1.83 ; 22$ deaths observed)(E Gilbert, personal communication); and in plutonium workers at the Rocky Flats weapons plant who accumulated a body burden of more than $74 \mathrm{~Bq}$ compared with those with lower body burdens (rate ratio $10 \cdot 6,95 \%$ confidence interval $0 \cdot 76$ to $127 \cdot 15) .{ }^{12}$ In none of these workforces was there an association between mortality and dose of external radiation. Only in one American workforce-namely, at the Pantex weapons facility - was mortality from prostatic cancer in radiation workers not above the national average, but the numbers were small (two deaths observed, 2.9 expected). ${ }^{9}$ Recent data from the Japanese atomic bomb survivors showed no association between a single acute exposure to high levels of external radiation 
and mortality from prostatic cancer, ${ }^{25}$ suggesting that excesses of prostatic cancer in these industrial workforces are unlikely to be due to external radiation, though an effect of protracted low level external exposure cannot be excluded.

The findings in this study and in the United Kingdom Atomic Energy Authority workforce indicate that only a small group of workers monitored for exposure to radionuclides who also had comparatively high exposures to external radiation were at increased risk of prostatic cancer. A characteristic of these men was that during their work they tended to be monitored for exposure to many different types of radionuclides, so it was not possible to examine the data separately for the independent effects of any single radionuclide. These men may also come into contact with chemicals and other substances, but no information on chemical exposure was collected for this or the United Kingdom Atomic Energy Authority study. There are no well documented causes of prostatic cancer, ${ }^{26}$ and, though cadmium has been proposed as a possible carcinogen, the evidence for this is weak. ${ }^{27}$ The prostate concentrates metals such as zinc and cadmium $^{28}$ but its uptake of radionuclides has not been studied in detail. We are carrying out a case-control study of prostatic cancer in the United Kingdom Atomic Energy Authority workforce to see whether its occurrence can be linked with any particular aspect of work..$^{29}$ Additional research needs to be carried out to discover which if any of the many substances to which nuclear workers are exposed are concentrated in the prostate.

When compared with the findings on mortality in other nuclear industrial workforces the results for cancer of the kidney are anomalous. An excess mortality was found in broadly the same group of workers for whom mortality from prostatic cancer was raised - that is, in radiation workers, especially those exposed to high doses of external radiation or who were monitored for internal contamination by radionuclides (tables V and IX). As with prostatic cancer, exposures were multiple and the same six workers accounted for most of the high standardised mortality ratios and rate ratios and for the statistically significant findings. Data on renal cancer were not presented separately for United Kingdom Atomic Energy Authority workers,? and in the three workforces for which data on renal cancer have been presented no unusual mortality patterns were noted. ${ }^{9} 10^{12}$ Uranium is concentrated in the kidney, ${ }^{30}$ and an excess mortality from nephritis but not renal cancer has been described in uranium miners. ${ }^{31}$ The standardised mortality ratio of 430 for renal cancer in workers monitored for exposure to uranium may be relevant, though based on only three deaths. Two of these three workers were also monitored for polonium, for which the standardised mortality ratio of 576 was significantly above 100 . Most uranium used at the Atomic Weapons Establishment is in an insoluble form and if anything tends to be inhaled (Atomic Weapons Establishment, personal communication), whereas polonium is concentrated in the kidney. ${ }^{32}$ As this is the only workforce in which cancer of the kidney has been associated with exposure to radiation, the possibility that these are chance findings cannot be ruled out.

Mortality from cancer of the bronchus and lung was lower in radiation workers than other employees, though the difference was not significant (standardised mortality ratios 64 and 93, respectively; rate ratio 0.84 ; $p=0 \cdot 30$ ). When, however, analyses were confined to radiation workers and exposures were lagged by 10 years there was a highly significant association between mortality from lung cancer and cumulative exposure $(p=0.001$; table VII $)$. The highly significant trend of increasing mortality from lung cancer with increasing exposure to external radiation was confined almost entirely to workers who were also monitored for internal contamination by radionuclides, especially plutonium (table XI). Generally similar associations were found for mortality from non-malignant respiratory diseases. An excess mortality from lung cancer has been reported among employees of the Y-12 nuclear weapons materials fabrication plant at Oak Ridge, where the main exposure was to inhaled insoluble uranium compounds; the excess risk was concentrated in workers jointly exposed to high doses of internal and external exposure, the rate ratio in those exposed to more than $50 \mathrm{mSv}$ of each being 4.5 (95\% confidence interval 0.91 to $23 \cdot 35) .{ }^{13}$ At the Portsmouth naval shipyard in New England an excess mortality from lung cancer has also been found in workers with at least $10 \mathrm{mSv}$ exposure to external radiation after a lag of 15 years; this excess was partly attributed to concomitant exposure to asbestos and welding fumes, but no information on internal exposure to radionuclides was reported. ${ }^{14}$

In the United Kingdom Atomic Energy Authority study no excess mortality from lung cancer was found in relation to external dose or in workers exposed to plutonium or other radionuclides, but no lagged analyses were performed in workers exposed to radionuclides. ${ }^{7}$ At the Rocky Flats nuclear weapons plant the rate ratio for lung cancer among those with a body burden of plutonium greater than $74 \mathrm{~Bq}$ compared with workers with a lower body burden was 0.67 ( $95 \%$ confidence interval 0.20 to 1.89 ) assuming no lag and $1.43(0.33$ to 4.65$)$ with a 10 year lag. Occupational exposure to plutonium is mostly by inhalation, and experiments have shown that inhaled plutonium causes lung cancer and chronic respiratory disease in animals ${ }^{30}$ but at dose levels considerably higher than those thought to be received by workers. No data on exposure to the lung from internal sources were collected for this study. Smoking is a strong determinant of lung cancer and risk of chronic respiratory disease, and without data on smoking habits or on exposure to the lung from internal sources firm conclusions cannot be drawn from these findings. Given the highly significant trends, further investigations are warranted, especially as in an independent inquiry in 1978 into safety standards at the Atomic Weapons Establishment air monitoring suggested that in certain operations exposures from inhaled plutonium may have exceeded internationally recommended limits. ${ }^{33}$

Cancers of the haemopoietic and lymphoid tissues were notable for their low occurrence in the Atomic Weapons Establishment study population and their lack of association with radiation exposure. Overall the standardised mortality ratios for leukaemia and multiple myeloma were below the national average ( 74 and 87 , respectively) and the mortality of workers with radiation records was lower than that in other workers (rate ratio 0.42 for leukaemia, rate ratio 0.62 for multiple myeloma). There were no deaths from either cause in workers accumulating more than $10 \mathrm{mSv}$ of external radiation exposure. Populations exposed to a single high dose of external radiation are at an increased risk of leukaemia, ${ }^{33}$ but the findings in industrial workforces have not been remarkable. ${ }^{1-14}$ In contrast, mortality from multiple myeloma has been significantly associated with increasing levels of exposure to external radiation in both the Sellafield and Hanford workforces. ${ }^{1410}$ Exposure to external radiation was considerably higher at those two establishments than at the Atomic Weapons Establishment, and with only two deaths from multiple myeloma in radiation workers at the Atomic Weapons Establishment the power of these data to show a similar trend is extremely low. Arguably the lack of an excess 
of these conditions is evidence that the observed associations for other cancers are unlikely to be due to exposure to radiation. Nevertheless, because of the small number of deaths in workers with a radiation record-four attributed to leukaemia, two to multiple myeloma-we cannot draw any firm conclusions about their relation to the level of radiation exposure. Furthermore, the absorbed doses to the tissues relevant for leukaemogenesis may not be the same as the absorbed doses in the lung and prostate.

The excess mortality from cancers of ill defined or secondary sites in radiation workers compared with other employees was due in part to the low mortality from this cause in the workers who were not monitored (table V). Similar findings have not been reported in other workforces, the opposite having been noted in Sellafield workers, ${ }^{10}$ and the findings here may be due to chance. In two thirds of those for whom the primary site was not specified a cancer had been registered, but in all but seven the primary cancer site was also unknown at the time of registration. Redistributing the seven cases with a specified primary site would not have altered the general conclusions, though the findings for prostatic cancer would have been strengthened.

Cancers of certain other specific sites are mentioned here in the context of the findings in other workforces. Tumours of the brain and nervous system have been reported to be in excess in workers in a nuclear fuel plant in Connecticut ${ }^{3}$ and in plutonium workers at the Rocky Flats nuclear facility. ${ }^{5}$ No excesses were found in our study, overall or in radiation workers, and the high rate ratios in workers monitored for contamination by radionuclides cannot readily be interpreted as they were based on only one death. The rate ratio of 2.09 for oesophageal cancer in workers monitored for exposure to plutonium (table IX) was not significant but was consistent with the excess mortality from oesophageal cancer found in Rocky Flats workers who had body burdens of plutonium exceeding $74 \mathrm{~Bq} .{ }^{12}$ The significantly high standardised mortality ratio and rate ratio for oesophageal cancer in workers monitored for contamination by actinium, based on two deaths, may be a chance finding (table IX). Both workers were also monitored for exposure to plutonium. Inhaled plutonium may be concentrated in bone and liver as well as lung. ${ }^{30}$ The two deaths from liver cancer and the one from bone cancer in radiation workers (table $\mathrm{V}$ ) were all in workers monitored for exposure to plutonium, but these numbers were too small to warrant separate analyses.

Smith and Douglas reported that after a lag of 15 years the mortality from bladder cancer increased significantly with increasing whole body exposure..$^{10}$ No unusual associations were noted in our series for bladder cancer and radiation exposure, except for a significant trend of increasing mortality with increasing surface exposure (but not whole body exposure) with a 15 year lag. The statistical significance was largely due to a single death from bladder cancer in the highest exposure category. The standardised mortality ratio of 300 for thyroid cancer, based on only two deaths in the Atomic Weapons Establishment radiation workers (and the standardised mortality ratio of 458 and rate ratio of 11.0 after a 10 year lag) was consistent with the reported standardised mortality ratios of 192 and 241, respectively, in United Kingdom Atomic Energy Authority and Sellafield radiation workers, though each standardised mortality ratio was based on only two deaths. ${ }^{710}$

Taking all malignant neoplasms together, the standardised mortality ratios were similar in workers with a radiation record and other workers, both being significantly below national mortality rates (table V).
Within workers with a radiation record mortality from all cancers was not related to cumulative external radiation exposure when no lag was assumed, regardless of the type of radiation exposure considered (tables VI and VIII). With a lag of 10 years, however, mortality from all malignant neoplasms increased significantly with increasing level of cumulative whole body exposure (table VII), with lung and, to a less extent, prostatic cancer contributing to the trend. Similar results were obtained regardless of the specific measure of external exposure used, and the magnitude of the excess became larger the longer the lag assumed (illustrated in table VIII). With a 10 year lag the relative risk was estimated, by using a multiplicative model, to increase by $7 \cdot 6 \%$ (95\% confidence interval $0 \cdot 4 \%$ to $15 \cdot 3 \%$ ) per $10 \mathrm{mSv}$ increment in exposure. By using an additive model an estimate of similar magnitude was obtained; this was higher than the corresponding estimates from the most recent analyses of mortality in the Japanese atomic bomb survivors. ${ }^{25} 34$

As workers with comparatively high exposures to external radiation are also likely to be monitored for possible internal contamination by radionuclides, the effects of these two exposures on mortality from cancer were examined simultaneously. When this was done the trend of increasing mortality with increasing exposure to external radiation was confined almost entirely to workers monitored for internal exposure to radionuclides (table XI). Internal exposure from inhaled or ingested plutonium, uranium, polonium, or actinium cannot be measured by dosimeters worn externally. Doses to organs depend crucially on the specific radionuclide and its distribution within the body and can be estimated only if the anatomical distribution of each specific radionuclide in individual workers is known. Other important factors are the route of intake and the time course of retention of radionuclides in organs. Such detailed information was not available for this study, so that we cannot assess the extent to which internally deposited radionuclides rather than exposure to external radiation might have accounted for the trends observed.

Members of the Epidemiological Monitoring Unit were funded by the Medical Research Council, which held a contract with the Ministry of Defence to perform the study. It was possible only because of the cooperation, patience, and advice of many people from different organisations, including the MRC, Atomic Weapons Establishment, United Kingdom Atomic Energy Authority, Office of Population Censuses and Surveys, NHS Central Register, DHSS, and the Oxford Cancer Registry. We thank all who helped us, and particularly Dr Robin Mole and staff at the London School of Hygiene, including Craig Higgins, Noreen Maconochie, Hazel Inskip, Michael Hills, Mark Verrill, Peter Smith, Abe Adelstein, Evelyn Middleton, and Nina Saroi.

1 Gilbert ES, Marks S. An analysis of the mortality of workers in a nuclear facility. Radiat Res 1979;79:122-48.

2 Rinsky RA, Zumwalde RD, Waxweiler RJ, et al. Cancer mortality at a naval nuclear shipyard. Lancet 1981; i:231-5.

3 Hadjimichael OC, Ostfeld AM, D'Atri DA, Brubaker RE. Mortality and cancer incidence experience of employees in a nuclear fuels fabrication plant. F Occup Med 1983;25:48-61.

4 Tolley HD, Marks S, Buchanan JA, Gilbert ES. A further update on the analysis of mortality of workers in a nuclear facility. Radiat Res 1983;95: 211-3.

5 Reyes M, Wilkinson GS, Tietjen G, Voelz GL, Acquavella JF, Bistline R. Brain tumors at a nuclear facility. $\mathcal{F}$ Occup Med 1984;26:721-4.

6 Fraser P, Booth M, Beral V, Inskip H, Firsht S, Speak S. Collection and validation of data in the United Kingdom Atomic Energy Authority validation of data in the United Kingdom

7 Beral V, Inskip H, Fraser P, Booth M, Coleman D, Rose G. Mortality of employees of the United Kingdom Atomic Energy Authority, 1946-79. BrMed f 1985;291:440-7.

8 Checkoway H, Mathew RM, Shy CM, et al. Radiation, work experience, and cause specific mortality among workers at an energy research laboratory. Brf Ind Med 1985;42:525-33.

9 Acquavella JF, Wiggs LD, Waxweiler RJ, MacDonell DG, Tietjen GL, Wilkinson GS. Mortality among workers at the Pantex weapons facility. Health Phys 1985;48:735-46.

10 Smith PG, Douglas AJ. Mortality of workers at the Sellafield plant of British Nuclear Fuels. Br Med f 1986;293:845-54.

11 Inskip H, Beral V, Fraser P, Booth M, Coleman D, Brown A. Further assessment of the effects of occupational radiation exposure in the United 
Kingdom Atomic Energy Authority mortality study. $\mathrm{Br} \mathcal{F}$ Ind Med 1987;44:149-60.

12 Wilkinson GS, Tietjen GL, Wiggs LD, et al. Mortality among plutonium and other radiation workers at a plutonium weapons facility. $A m \mathcal{F}$ Epidemiol 1987;125:231-50.

13 Checkoway H, Pearce N, Crawford-Brown DJ, Cragle DL. Radiation doses and cause-specific mortality among workers at a nuclear materials fabrication plant. Am ₹ Epidemiol 1988;127:255-66.

14 Rinsky RA, Melius JM, Hornung RW, et al. Case-control study of lung cancer in civilian employees at the Portsmouth naval shipyard, Kittery, Maine. Am F Epidemiol 1988;127:55-64.

15 Office of Population Censuses and Surveys. Classification of occupations 1970. London: HMSO, 1970.

16 World Health Organisation. International classification of diseases, injuries and causes of death. 8th Revision, 1965. Geneva: WHO, 1967.

17 World Health Organisation. International classification of diseases, injuries and causes of death. 9th Revision, 1975. Geneva: WHO, 1977.

18 Smith JW, Inskip H. Estimation of below measurement threshold doses following the remeasurement of a sample of old films. Fournal of the Society for Radiological Protection 1985;5:159-64.

19 Bailar JC, Ederer F. Significance factors for the ratio of a Poisson variable to its expectation. Biometrics 1964;20:639-43.

20 Breslow NE, Day NE. Statistical methods in cancer research. Vol II. The design and analysis of cohort studies. Lyons: International Agency for Research on Cancer, 1987. (IARC scientific publications, No 82.)

21 Office of Population Censuses and Surveys. Occupational mortality, 1970-72. Decennial supplement. London: HMSO, 1978. (Series DS, No 1.)

22 Day NE, Boice JD Jr, eds. Second cancer in relation to radiation treatment for cervical cancer. Lyons: International Agency for Research on Cancer, 1983. (IARC scientific publications, No 52.)

23 Beral V, Fraser P, Booth M, Carpenter L. Epidemiological studies of workers in the nuclear industry. In: Russell Jones R, Southwood R, eds. Radiation and health. Chichester: Wiley, 1987:97-106.

24 Beral V, Carpenter L, Booth M, Inskip H, Brown A. The "healthy worker effect" and other determinants of mortality in workers in the nuclear industry. In: Health effects of low dose ionising radiation-recent advances and their implications. London: British Nuclear Energy Society, 1988:95-100.

25 Shimizu Y, Kato H, Schull WJ, Preston DL, Fujita S, Pierce DA. Life span study report 11. Part 1. Comparison of risk coefficients for site-specific cancer mortality based on the DS86 and T65DR shielded Kerma and Organ doses. Radiation Effects Research Foundation Technical Report Series 1987; doses. Radicior

26 Alderson MR. Prostate cancer: epidemiology. Recent Results Cancer Res 1981;78:1-19.

27 Piscator $M$. Role of cadmium in carcinogenesis with special reference to cancer of the prostate. Environ Health Perspect 1981;40:107-20.

28 Schroeder HA, Nason AP, Tipton IH, Balassa JJ. Essential trace metals in man: zinc. Relation to environmental cadmium. $f$ Chronic Dis 1967;20: 179-210.

29 Fraser P, Beral V, Booth M, Inskip H, Carpenter L. Epidemiological studies of employees of the United Kingdom Atomic Energy Authority. In: Health effects of low dose ionising radiation-recent advances and their implications. London: British Nuclear Energy Society, 1988:67-70.

30 Hodge HC, Stannard JN, Hursh JB. Uranium, plutonium and the transplutonic elements. New York: Springer Verlag, 1973.

31 Waxweiler RJ, Roscoe RJ, Archer VE, Thun MJ, Wagoner JK, Lundin FE Jr. Mortality follow-up through 1977 of the white underground uranium miners cohort examined by the United States Public Health Service. In: Gomez M, ed. Radiation hazards in mining. Kingsport: Kingsport Press, 1981:823-30. 32 International Commission for Radiological Protection. Limits of intakes of radionuclides by workers. Part 1. Ann ICRP 1979; No 30:1-116.

33 Pochin E. Report of an investigation into radiological health and safery at the Ministry of Defence (Procurement Executive) Atomic Weapons Research Establishment, Aldermaston. Harwell, Oxfordshire: Atomic Weapons Research Establishment, 1978.

34 Preston DL, Pierce DA. The effect of changes in dosimetry on cancer mortality risk estimates in the atomic bomb survivors. Radiation Effects Research Foundation Technical Report Series 1987; No 9:1-50.

(Accepted 5 August 1988)

\title{
Surveillance of antibody to measles, mumps, and rubella by age
}

\author{
Peter Morgan-Capner, Jean Wright, Christine L Miller, Elizabeth Miller
}

\begin{abstract}
Before the introduction of measles, mumps, and rubella vaccine a survey was carried out to measure antibody prevalence to the three viruses by age. A total of 8716 samples of serum collected by five public health laboratories in different parts of England during 1986-7 were tested. Despite the current measles vaccination programme $60 \%$ of children aged 1-2 years did not have measles antibody and over $80 \%$ did not have antibodies to mumps and rubella. In the 3-4 year age group $17 \%$ of the children were susceptible to measles, $55 \%$ to mumps, and $73 \%$ to rubella. The results suggest that vaccinating children early in the second year of life will be necessary to eliminate the three diseases.
\end{abstract}

The survey provides baseline data for continuing surveillance of the immediate and long term effects of the new vaccination strategy.

\section{Introduction}

Development of effective strategies of vaccination and assessment of their impact require knowledge of the prevalence of antibody by age for the diseases concerned. Preceding the introduction of measles, mumps, and rubella vaccine, a study of antibody prevalence to measles, mumps, and rubella viruses across the age range 1-65 years and over has been carried out. This has provided information on the most suitable age for vaccination and baseline data on antibody prevalence as part of continuous surveillance to monitor both immediate and long term effects of introducing the vaccine.

\section{Subjects and methods}

In five public health laboratories (Ashford, Bristol, Leeds, Manchester, and Preston) serum remaining from samples submitted for routine diagnostic examination was saved from patients aged 1-65 years and over. Samples from immunocompromised patients and samples sent for testing for antibody to hepatitis B and the human immunodeficiency virus were excluded.

The serum samples were tested for rubella antibody by radial haemolysis ${ }^{1}$ in each laboratory. Samples giving zone sizes greater than that of a control serum containing 15 IU rubella antibody were recorded as positive and those with no zone as negative. Samples giving small zones compared with the control serum or zones on both test and control gels were retested at Preston Public Health Laboratory by latex agglutination (Orion Diagnostica, Espoo, Finland) and recorded as positive or negative accordingly. Samples were tested for measles and mumps antibodies at Preston Public Health Laboratory. Mumps antibody was detected by radial haemolysis. ${ }^{2}$ A serum (arbitrarily assigned as having 50 units of antibody) from a person who had had mumps in the remote past was diluted in negative serum. At a dilution of one in 10 (5 antibody units) antibody was reproducibly detected by radial haemolysis during preliminary evaluation, and this dilution was tested on every gel. Test samples giving zones of haemolysis greater than that of the diluted standard were considered to 're positive and those giving no zone negative. Samples giving zones on test and control gels were retested after absorption with day old chick red cells and non-infected allantoic fluid. Samples giving zones less than that of the diluted standard were retested with a commercial antiglobulin enzyme linked immunosorbent assay (ELISA) (Behringwerke AG, Marburg, West Germany) and classified according to result. Measles antibody was detected by haemagglutination inhibition. ${ }^{3}$ Serum samples were compared with a serum standardised against the first British standard human antimeasles serum and samples with a concentration equal to or greater than $0.3 \mathrm{IU}$ (usually a titre of 8 by haemagglutination inhibition) were considered to be positive, and those with a concentration below $0 \cdot 15 \mathrm{IU}$ negative. Samples with a concentration of $0 \cdot 15$ IU were retested with a commercial antiglobulin ELISA and assigned as positive or negative according to the result 